\title{
ON THE GENUS HEDWIGIA (HEDWIGIACEAE, BRYOPHYTA) IN RUSSIA
}

\section{К СИСТЕМАТИКЕ РОДА НЕDWIGIA (HEDWIGIACEAE, ВRYOРНYТА) В РОССИИ}

\author{
ELENA A. IGNATOVA ${ }^{1}$, OXANA I. KuZNETSOVA ${ }^{2}$, Vladimir E. FEDOSOV ${ }^{1} \&$ \\ MICHAEL S. IGNATOV ${ }^{1,2}$ \\ ЕЛЕНА А. ИГНАТОВА ${ }^{1}$, ОКСАНА И. КУЗНЕЦОВА ${ }^{2}$, ВЛАДИМИР Э. ФЕДОСОВ ${ }^{1}$, \\ МИХАИЛ С. ИГНАТОВ ${ }^{1,2}$
}

\begin{abstract}
An integrative molecular and morphological study of the genus Hedwigia in Russia revealed at least five distinct species in its territory. Hedwigia czernyadjevae sp. nov. appears to have a wide distribution in Transbaikalia, Yakutia and high mountains of the Russian Far East, although it never occurs frequently. Previously its specimens were identified as H. stellata, but straight leaf apices, strongly incrassate and porose laminal cells and hairy calyptrae differentiate $H$. czernyadjevae from this species, in addition to sequence data, which place the Siberian species closer to American $H$. detonsa. Hedwigia nemoralis sp. nov. occurs in southern regions of Russia, from the Caucasus to the Russian Far East, with one locality in Central European Russia. It was also revealed from eastern North America. It is characterized by a small plant size, shortly acuminate, secund leaves with short, denticulate hyaline hair points and weakly ciliate perichaetial leaves. Hedwigia mollis sp. nov. has shortly recurved leaf margins, weakly sinuose laminal cells and spores $20-25(-28) \mu \mathrm{m}$. It was revealed in European Russia, from the southern Murmansk Province and Karelia to the Caucasus, and from South Urals and Altai Mts. Hedwigia ciliata is infrequent in Russia, occurring mainly in the North-Western European Russia, with few localities in its central part. It is characterized by longly recurved leaf margins, sinuose laminal cells and spores (27.5-)30-35(37.5) $\mu \mathrm{m}$. Numerous collections in herbaria from the Caucasus and Asian Russia are referred to H. emodica, which turned out to be rather uniform by morphology. In addition to long hyaline leaf apices, it is characterized by straight leaves, almost plane leaf margins and dense papillae with thick, obtuse branches. Descriptions and illustrations for all five species of the genus revealed in Russia, as well as a key to the identification of Hedwigia species in Russia are provided. Four of these species received a high support in the molecular phylogenetic analysis based on chloroplast trnL-F, mitochondrial nad5 and nuclear ITS1-2 sequences, while $H$. emodica was found in an unresolved grade. Some collections require further studies, and this first attempt to estimate the species diversity of Hedwigia in Russia highlights the complicated problems, likely caused by hybridization between closely related species.
\end{abstract}

Резюме

Интегративный подход к изучению рода Hedwigia в России с помощью молекулярно-филогенетических и морфологических методов выявил на ее территории по меньшей мере 5 видов. Hedwigia czernyadjevae sp. nov. распространена от Забайкалья до Якутии и высокогорий Российского Дальнего Востока, хотя нигде не растет массово. Образцы этого вида ранее определялись как H. stellata, однако H. czernyadjevae отличается от этого вида прямыми верхушками листьев, клетками с сильно утолщенными и пористыми стенками и сильно волосистыми колпачками, в дополнение к тому, что молекулярно-филогенетические данные свидетельствуют о более близком родстве сибирского вида с североамериканской H. detonsa. Hedwigia nemoralis sp. nov. встречается в южных регионах России, от Кавказа до российского Дальнего Востока; единичное местонахождение выявлено также в центре европейской части России. Кроме того, этот вид встречается на востоке Северной Америки. Hedwigia nemoralis характеризуется мелкими размерами растений, коротко заостренными листьями с короткими, пильчатыми гиалиновыми волосками и перихециальными листьями со слабо развитыми ресничками. Hedwigia mollis sp. nov. имеет слабо отогнутые края листа, клетки со слабо выемчатыми стенками и споры 20 $25(-28) \mu \mathrm{m}$. Этот вид выявлен на территории европейской части России, от юга Мурманской области и Карелии до Кавказа, на Южном Урале и Алтае. Распространение H. ciliata на

\footnotetext{
1 - Lomonosov Moscow State University, Faculty of Biology, Geobotany Dept., Leninskie Gory Str. 1-12, Moscow 119234 Russia - Россия, 119234, Москва, Ленинские Горы, д. 1 стр. 12, Московский государственный университет, биологический факультет, кафедра геоботаники; email: fedosov v@mail.ru \& arctoa@list.ru

2 - Tsitsin Main Botanical Garden, Russian Academy of Sciences, Botanicheskaya Str., 4, Moscow 127276 Russia - Россия 127276 Москва, Ботаническая 4, ГБС РАН
} 
территории России ограничено северо-западными регионами европейской части, с единичными местонахождениями в ее центре. Для этого вида характерны листья с высоко отогнутыми краями, клетки с извилистыми стенками и споры (27.5-)30-35(37.5) $\mu \mathrm{m}$. Многочисленные гербарные коллекции с Кавказа и из Азиатской части России отнесены к H. emodica. Эти образцы морфологически довольно однородны и отличаются, помимо длинных гиалиновых верхушек листьев, прямыми листьями с почти плоскими краями и густыми папиллами с толстыми тупыми ветвями. Для выявленных в России видов Hedwigia приводятся описания, иллюстрации и ключи для определения. Отсеквенированные образцы четырех видов образовали высоко поддержанные клады в молекулярно-филогенетическом дереве, основанном на последовательностях ДНК хлоропластного маркера $t r n \mathrm{~L}-\mathrm{F}$, митохондриального $n a d 5$ и ядерного ITS1-2; образцы $H$. emodica образовали неразрешенную граду в основании одной из клад. Некоторые образцы из России нуждаются в дополнительном изучении, и эта первая попытка оценки видового разнообразия в роде Hedwigia в России подчеркивает некоторые сложные таксономические проблемы, вероятно, связанные с гибридизацией близкородственных видов.

KEYWORDS: mosses, taxonomy, new species, molecular phylogenetics, ITS, trnL-F, nad5

\section{INTRODUCTION}

Until recently, the genus Hedwigia P. Beauv. was thought to be monospecific, containing the widespread and easily recognized species Hedwigia ciliata (Hedw.) P. Beauv. with a worldwide distribution (Anderson et al., 1990; Corley et al., 1981; Ignatov \& Afonina, 1992; Iwatsuki, 2004). Though a number of species and varieties were described within this genus during 19th and early 20th century (see Hedenäs, 1994 and Biasuso, 2007 for overviews), since Brotherus (1925) they were for a long time considered as synonyms of $\mathrm{H}$. ciliata. However, a revision of the Hedwigia ciliata complex in Sweden (Hedenäs, 1994) resulted in recognition of three taxa in Europe, including $H$. ciliata var. ciliata, $H$. ciliata var. leucophaea Bruch, Schimp. \& W. Gümbel and the newly described $H$. stellata Hedenäs. The latter species was reported from southern Sweden, southern Norway, Denmark and Åland Islands in Finland. Subsequently, Erzberger (1996) reported H. stellata from other European countries; Buck \& Norris (1996) recognized it in the coastal area in western North America and raised the Californian endemic Hedwigia detonsa (M. Howe) W.R. Buck \& D.H. Norris to the species rank. They also pointed out that the material of Hedwigia from Latin America is probably distinct from the common H. ciliata in North America and should be recognized as $H$. nivalis (Müll. Hal.) Mitt. Biasuso (2007) in her revision of the genus in Argentina accepted the latter taxon at the level of variety, $H$. ciliata var. nivalis Hampe. She also reported $H$. ciliata var. ciliata from Argentina and considered it as the most frequent and abundant taxon of the genus in the highlands of the country. In addition, she described a new species, $H$. brevipilifera Biasuso with a restricted distribution in cold grasslands and open forests in mountain areas of Argentina. Hedwigia ciliata was also reported by Dalton et al. (2013) from Sino-Himalaya; they also recorded H. stellata as new to India, Nepal and Bhutan, and H. emodica Hampe ex Müll. Hal. (=H. ciliata var. leucophaea) as new to Nepal and China.

A first molecular based study of relationships in the Hedwigiaceae was conducted by Buchbender et al. (2014).
It was focused on the generic concepts within the family as well as on mainly European species of the genus Hedwigia. Sequence data from mitochondrial, chloroplast and nuclear DNA were used for their phylogenetic reconstruction, i.e., nad5, trnL-F and ITS 1-2. It was shown that at least four species of $H$. ciliata complex occur in Europe, including $H$. ciliata s. str., $H$. stellata, $H$. striata (Wilson) Bosw. and a cryptic species with unclear identity. At the same time, it was demonstrated that $H$. ciliata var. leucophaea cannot be considered as a distinct taxon, as its distinctive morphological characters were probably developed independently in various taxa, some of them being of hybrid origin. In addition, transferring of Pseudobraunia californica (Lesq.) Broth. into the genus Hedwigia was suggested and a separate status of $\mathrm{H}$. ciliata var. nivalis was confirmed. The presence of some other cryptic species within $H$. ciliata complex was proposed, due to a separate position of Australian specimens in the molecular phylogenetic trees and absence of obvious morphological distinction of these specimens.

In Russia, the genus Hedwigia has never been the focus of a taxonomic revision. Species of the genus are rather common in mountain areas of Russia and rare in lowlands, being found in places were rock substrates are present. In European Russia, Hedwigia occurs from the Murmansk Province and Komi Republic in the north to the Caucasus in the south; in Asian Russia it is more frequent in southern Siberia and the southern Far East, but it is also present in Taimyr, Yakutia, Kamchatka and Chukotka, however avoiding Arctic regions. Ignatov \& Afonina (1992) reported only one species, H. ciliata, for the former USSR. Later on, H. stellata was reported from Bureinsky Nature Reserve, Khabarovsk Territory (Ignatov et al., 2000), however with the remark that this identification is questionable because of some morphological differences from European plants (not reflexed leaf apices). This record was also included into the Check-list of mosses of East Europe and North Asia (Ignatov, Afonina, Ignatova et al., 2006). Hedwigia stellata was also reported from Zabaikalsky Territory (Afonina \& Czernyadjeva, 2012; Afonina et al., 2012) based 
on specimens similar to those from Khabarovsk Territory. The uncertain identity of these Asian ' $H$. stellata', as well as the overall morphological variation of herbarium collections of Hedwigia from the territory of Russia initiated the present study, including the use of molecular markers.

\section{MATERIAL AND METHODS}

The material for the present DNA studies was selected mainly in MHA and MW; some duplicates from LE were also used.

\section{Molecular phylogenetic study}

For molecular study we used three markers: nuclear internal transcribed spacers 1 and $2 \& 5,8 \mathrm{~S}$ RNA gene (ITS), the intronic region of the mitochondrial NADH dehydrogenase subunit 5 (nad5) and the intronic region of the chloroplastic trn $\mathrm{L}$ gene \& trnL-trnF intergeneric spacer $(\operatorname{trn} L)$. DNA extraction and amplification were done according to the laboratory protocols described in Gardiner et al. (2005) and Fedosov et al. (2016). The newly obtained data were supplemented by sequences available in GenBank. Rhacocarpus purpurascens (Brid.) Paris, Braunia alopecura (Brid.) Limpr., B. imberbis (Sm.) N. Dalton \& D.G. Long and Hedwigia californica (Lesq.) Kindb. were included as outgroups. Totally 219 sequences from 74 specimens were involved into the analysis, including 153 sequences of 52 specimens obtained de novo. Vouchers of newly sequenced specimens and GenBank accession numbers are compiled in Appendix 1. Sequences were aligned for each gene independently using BioEdit version 7.0.9.0 Sequence Alignment Editor (Hall, 1999). Absent positions at the 3'- and 5'-ends were treated as missing data.

We conducted analyses of individual alignments, namely ITS (755 bp, 74 sequences), trnL (428 bp, 73 sequences) and nad5 (1115 bp, 72 sequences), concatenated organellar dataset of trnL-nad5 (1543 positions), and concatenated ITS-trnL-Nad5 sequences (2298 positions). Individual datasets were divided into unlinked partitions corresponding to ITS1, 5.8SRNA gene, ITS2; the exon in $\operatorname{trn} L$ gene, the intron in $\operatorname{trn} L$ gene, $\operatorname{trn} L$-trnF spacer, $\operatorname{trn} F$ gene; three codon positions for coding portion of the $\mathrm{Nad} 5$ gene, the intron in the Nad5 gene. The combined datasets were separated into eight and eleven unlinked partitions correspondingly. Best-fit substitution models were identified for each gene separately, and for combined dataset using ModelgeneratorV.85 (Keane et al., 2006).

. Best-scoring Maximum Likelihood (ML) trees were estimated using RaxML (Stamatakis, 2006) from 1000 independent searches each starting from distinct random trees. Robustness of the nodes was assessed using the thorough bootstrapping algorithm (Felsenstein, 1985) with 1000 iterations. RaxML was performed on the Cipres Science Gateway (http://www.phylo.org/portal2), using RAxML-HPC2 on XSEDE. Mamimum parsimony analysis was completed with Nona (Goloboff, 1994) within the Winclada shell (Nixon, 1999), with bootstrap calcu- lation with 2000 replications. Bayesian Analyses (BA) were performed running two parallel analyses. For single gene analyses each run consisted of six Markov chains and 10,000,000 generations with default number of swaps chains and a sampling frequency one tree each 5,000 generations. For concatenated dataset the analysis consisted of eight Markov chains and 50,000,000 generations with the number of swaps chains set to five and a sampling frequency one tree each 10,000 generations was performed. The chain temperature was set at 0.02 in all analyses. Convergence of each analysis was evaluated using Tracer1.4.1 (Rambaut \& Drummond, 2007) to check that all ESS values exceeded 200. Consensus trees were calculated after omitting the first $25 \%$ trees as burnin. Analyses were performed on the Cipres Science Gateway (http://www.phylo.org/portal2), using MrBayes 3.2.6 (Ronquist et al., 2012) on XSEDE. All trees were rooted on Rhacocarpus purpurascens.

\section{Morphology}

Standard morphological and anatomical methods were used. Plants, capsules and perichaetial leaves were photographed with a stereomicroscope (Olympus SZX16) equipped with an Infinity 4 digital camera. Some stacked micrographs using several optical sections were composed using the software package HeliconFocus 4.50 (Kozub et al., 2008). Measurements were taken with Zeiss and Leitz light microscopes, cell sizes were measured on digital photos made with a Nikon D70 camera and with the use of Infinity Analyze 5.0.2 Software. Drawings were made with MBS10 stereo microscope and LOMO Mikmed-2 light microscope with an aid of the Wild Heerbrugg TYP 308700 and RA6U42 drawing tubes. Observations of leaf surface structure and spore surface ornamentation were done with the SEM Cambridge Instruments CamScan S2 and LEO 430 for specimens coated by gold without additional preparation; leaves were also studied with LSCM Olympus FV1000. For LSCM observation, leaves were taken from herbarium collections, placed on slides into deionized water, stained by berberine and investigated with 405 and $473 \mathrm{~nm}$ lasers.

\section{RESULTS}

All obtained trees demonstrate similar topology of basal clades. Five Braunia specimens form maximally supported clade sister to Hedwigia (Fig. 1). Maximally supported Hedwigia-clade starts with H. californica, and then the highly supported terminal clade includes the rest of species. The topologies within this clade differ in trees based on the concatenated ITS-trnL-nad5 dataset (Fig. 1), the ITS-based tree (Fig. 1A), tree from organellar sequences (Fig. 1B), as well as in trees obtained from trnL-F and nad5 (not presented).

The terminal clade in the tree from the concatenated dataset (Fig. 1) subdivides into $H$. detonsa and the highly supported clade $\left(\mathrm{PP}=1, \mathrm{BS}=98 / 92^{1}\right)$ with the rest of

${ }^{1}$ - Bootstrap is shown in two values, from ML and MP analyses, correspondingly 


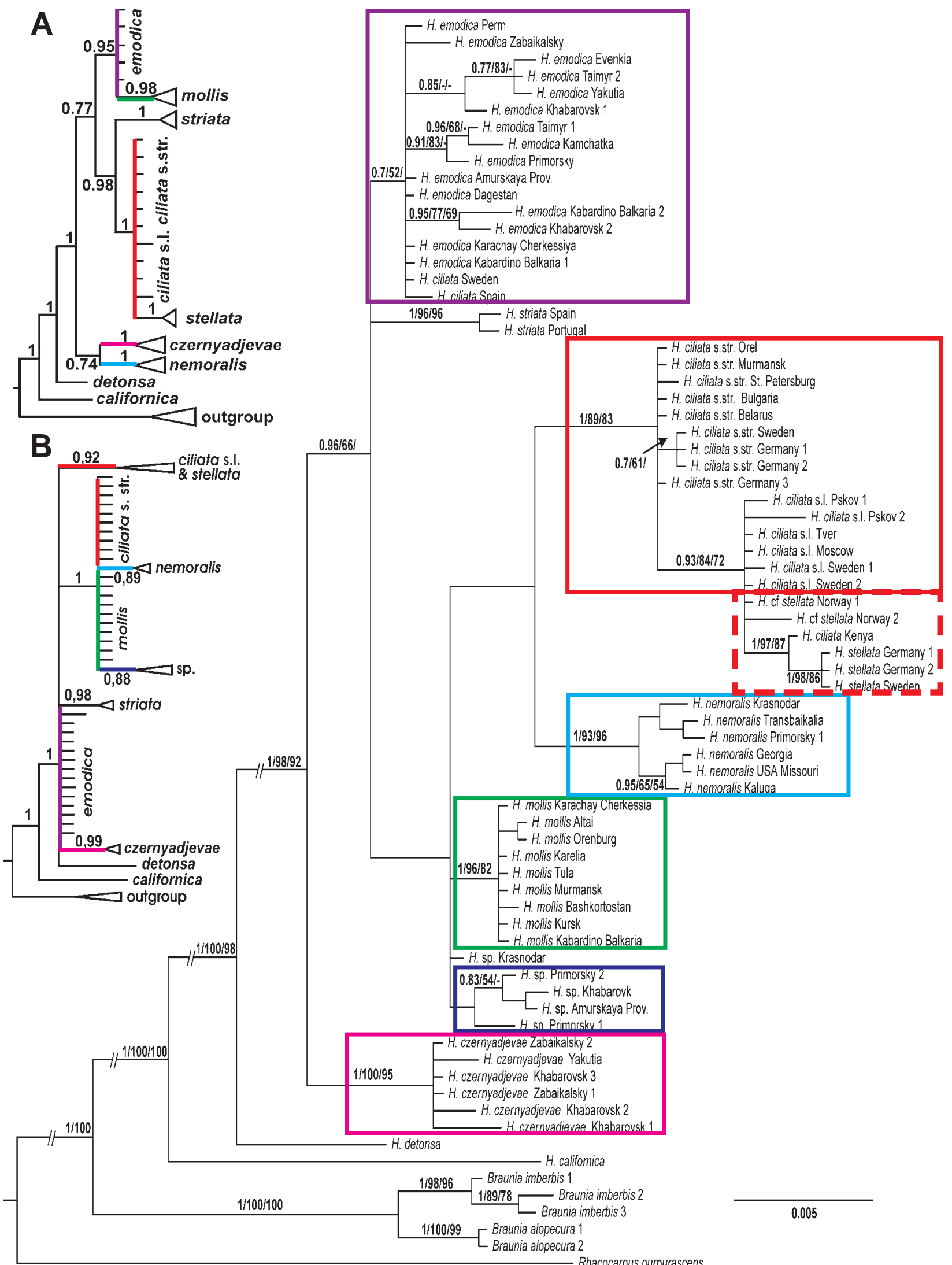

Fig. 1. Bayesian tree from concatenated dataset of nuclear ITS1-2, mitochondrial nad5 and chloroplastic $\operatorname{trn} \mathrm{L}-\mathrm{F}$. Posterior probabilities $(>0.7)$ and bootstrap supports $(>50)$ from ML and MP are above branches. Frame colors correspond to the maps in Fig. 2. Dash-line marks H. stellata and similar plants, discussed under H. ciliata. Small tree schemes show topologies inferred from Bayesian analysis of ITS (A) and $n a d 5+\operatorname{trn} \mathrm{L}-\mathrm{F}(\mathrm{B})$. 

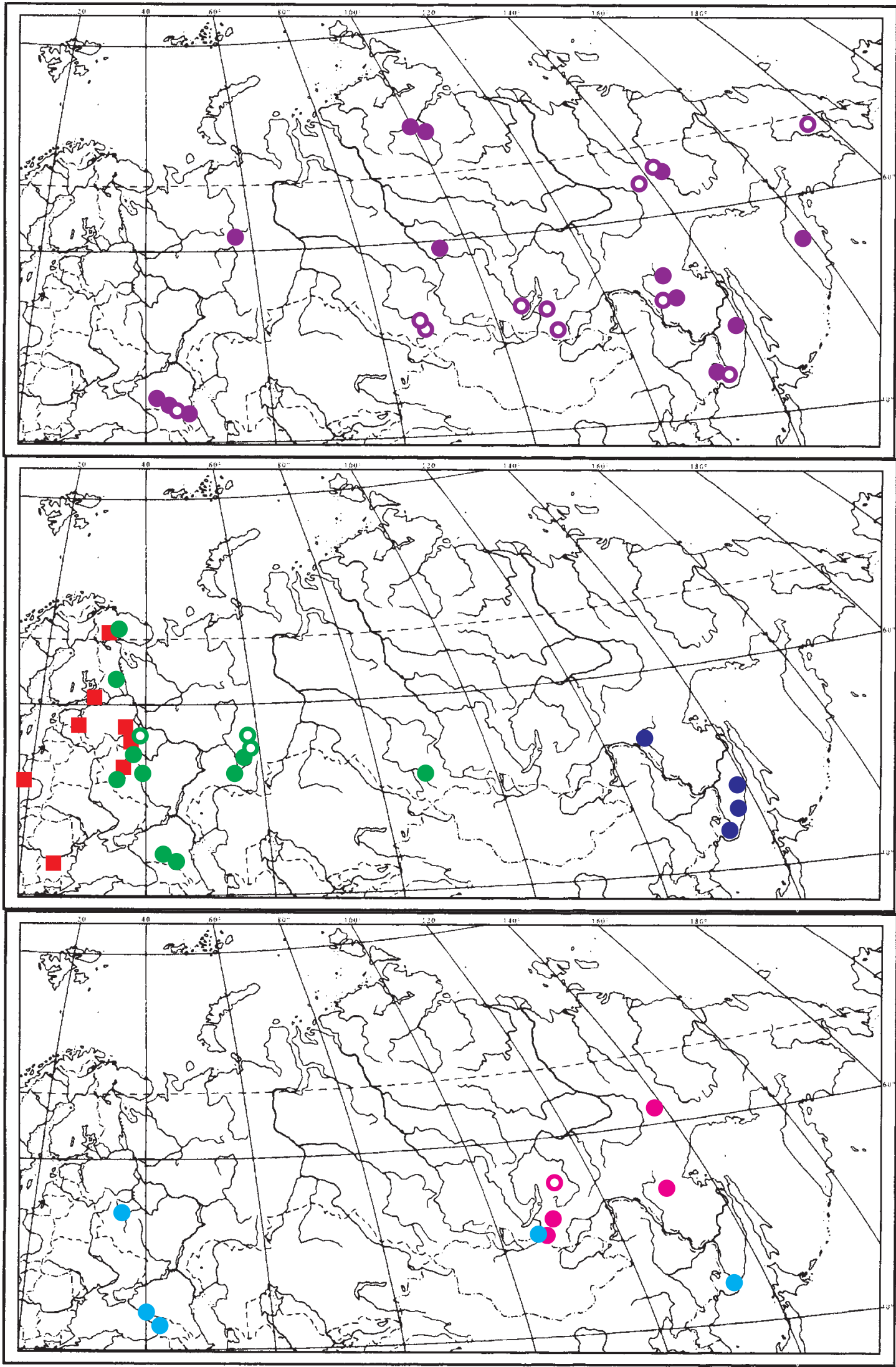

Fig. 2. Distribution of the speices of Hedwigia in Russia and adjacent countries. Hedwigia nemoralis: ; H. czernyadjevae: ; H. ciliata: $\square$; H. mollis: ; Hedwigia sp. (Russian Far East): ; H. emodica: O. Solid figures - sequenced specimens; hollow figures - specimens identified from herbarium collections. Color of figures corresponds to clades in the molecular-phylogenetic tree in Fig. 1. 
species. This latter comprises a grade. Its first branch is formed by a highly supported clade $(\mathrm{PP}=1, \mathrm{BS}=100$ / 95) composed by morphologically homogeneous and geographically united plants of 'Siberian $H$. stellata' that are described below as a new species, $H$. czernyadjevae.

Second branch includes a polytomy of $H$. striata-clade $(\mathrm{PP}=1, \mathrm{BS}=98 / 98)$ and unsupported clade of our specmens referred to $H$. emodica (more known as $H$. ciliata var. leucophaea) and two sequences from GenBank from Spain and Sweden named H. ciliata (specimens not studied by us).

Third branch also has a polytomy that includes five samples left unnamed as $H$. sp. and one highly supported clade $(\mathrm{P}=1, \mathrm{BS}=96 / 82)$. The latter comprises morphologically rather homogeneous plants, thus it is described below as one more species, $H$. mollis. Four of unnamed specimens form a weakly supported clade (marked in blue in Fig. 1); they represent the eastern margin of the Hedwigia distribution in Eurasia.

Fourth branch includes a clade with high support $(\mathrm{PP}=1, \mathrm{BS}=92 / 98)$. Six specimens from southernmost parts of Russia and one specimen from North America are morphologically homogeneous; they are described below as a third new species, $H$. nemoralis.

Then a rather highly supported clade $(\mathrm{PP}=1, \mathrm{BS}=89$ / 82 ) is formed by mainly European specimens (plus one plant from Africa). They are referred to $H$. ciliata and $H$. stellata.

In the ITS based Bayesian tree (Fig. 1A), the discussed terminal clade starts with $H$. detonsa. It is sister to the rest species that form a clade with $\mathrm{PP}=1$. This clade comprises two weakly supported subclades. The first of them includes two maximally supported clades of $H$. czernyadjevae and $H$. nemoralis. The second clade includes two clades, one of $H$. ciliata, $H$. stellata and $H$. striata $(\mathrm{PP}=0.98)$ and another with specimens of $H$. emodica, $H$. mollis, $H$. sp. and two specimens of $H$. ciliata from GenBank $(\mathrm{PP}=0.95)$.

The tree based on organellar markers has a poor resolution, and even $H$. detonsa appeares within the extensive polytomy of $H$. emodica plus two GenBank specimens of H. ciliata and four nested clades: (1) H. czernyadjevae, $\mathrm{PP}=0.99$; (2) H. striata, $\mathrm{PP}=0.98$; (3) H. ciliata s.l. plus $H$. stellata, $\mathrm{PP}=0.92$; (4) H. ciliata s.str., H. nemoralis, $H$. mollis and $H$. sp., $\mathrm{P}=1.00$. Within the latter clade $H$. nemoralis forms a nested clade with moderate support $\mathrm{PP}=0.89$.

The maximum parsimony analysis of the ITS-trnLnad5 dataset (not shown) yields the same topology at the tree base (Braunia, H. californica, H. detonsa), and then a polytomy with nested clades of highly supported $H$. czernyadjevae, $H$. nemoralis and moderately supported clades of $H$. mollis and $H$. ciliata (with nested supported clades of $H$. stellata and $H$. striata). The composition of the polytomy is similar to that in the Bayesian tree.
The topology obtained from maximum likelihood analysis of the ITS-trnL-nad5 dataset (not shown) is nearly identical to those inferred from Bayesian and MP analyses. Highly supported $H$. czernyadjevae clade splits on the next node after $H$. detonsa. Well supported $H$. mollis-clade and $H$. nemoralis-clade form weakly supported clade sister to separate, though weakly supported $H$. emodica-clade. Specimens considered as H. ciliata s.str. and $H$. ciliata s.l. form well supported separate clades with highly supported $H$. stellata-clade nested in $H$. ciliata s.l.-clade.

\section{DISCUSSION}

The topology of the Bayesian tree based on concatenated sequences is in general congruent with the tree obtained by Buchbender et al. (2014), which is natural, as all sequences of outgroup taxa were borrowed from that publication. The differences occur in the terminal supported clade, where smaller highly supported clades were found.

Specimens from Asian Russia reported with question mark under the name $H$. stellata do not belong to this species according to the obtained molecular data. Their position in the molecular phylogenetic tree (Fig. 1) indicates high distinctiveness of this taxon from all other Russian representatives of Hedwigia; it is described below as a new species, $H$. czernyadjevae.

The broad sampling outlined two additional clades that also represent undescribed species (Fig. 1, H. nemoralis and $H$. mollis). Specimens from the obtained clades were carefully studied for their morphology, and a number of characters allowing their differentiation were revealed, despite overall similarity with $H$. ciliata. Subsequent checking of numerous herbarium collections has shown that the found distinctions are stable and can be introduced for practical identification.

The most complicated is situation with Hedwigia ciliata, which appeared to be very rare in Russia, restricted mostly to the North-West and West of its European part (see discussion under H. ciliata).

So far, the nomenclatural problems concentrate around the name $H$. ciliata and its variety leucophaea and cannot yet be completely solved. Therefore we did not focus on studies of possible nomenclatural types, postponding this for further studies. Thus, a large group of specimens, mainly from Asian Russia, with morphology of $H$. ciliata var. leucophaea sensu Hedenäs (1994) is discussed below under the name H. emodica Hampe ex Müll. Hal. Contrary to the results of Buchbender et al. (2014), our sequence data indicate that it likely is a taxon deserving species status. Here we follow Dalton et al. (2013) who also used this name for Hymalayan taxon with morphological characters similar to North Asian plants.

As the discussion of the molecular results should be more interesting in combination with morphology, we deal with these under the species descriptions. 


\section{TAXONOMY}

\author{
Hedwigia P. Beauv., Mag. Encycl. 9(5[19]): 304.
} 1804.

Plants medium-sized, rigid, dull, greyish-green, often forming large cover on rock surfaces. Stems irregularly branched, without central strand and hyalodermis. Stem leaves imbricate when dry, straight or secund, with straight or recurved apices, widely spreading when wet, widely or narrowly ovate, gradually narrowed to the apex or acuminate, concave, with short or long hyaline hairpoints or hyaline apical parts; margins widely or narrowly recurved in lower $1 / 5-3 / 4$ or to the base of hairpoint, occasionally almost plane throughout, entire below, obtusely to sharply denticulate in distal hyaline area; costa absent; cells in mid-leaf short rectangular, moderately to strongly thick-walled, walls straight or sinuose, non-porose or porose, papillose on both surfaces, papillae 1-3(-4) per cell, on abaxial surface papillae branched, with short or long branches, peltate or non-peltate; on adaxial surface papillae less numerous, less strongly branched, occasionally also simple; cells in the middle of leaf base rectangular to linear, usually thick-walled, porose, orange-brown, lowermost cells smooth, then gradually becoming papillose, papillae seriate, simple; zone of long cells more or less abruptly transiting into densely papillose median laminal cells; basal marginal cells subquadrate, rectangular and transversely rectangular, with thickened and often porose transverse walls. Autoicous, sporophytes frequent or rare. Perichaetial leaves longer than stem leaves, with longer hair-points, with long, flexuose cilia at margins. Vaginulae hairy. Setae short, straight. Capsules immersed, obovoid, turbinate or cuplike. Exothecial cells rectangular in the middle and lower part of urn, thin- or thick-walled, with immersed stomata at base of urn, exothecial cells at urn mouth in several rows transversely rectangular, quadrate and short rectangular, thick-walled, darker colored. Peristome absent. Operculum low conic, mammillate. Spores heteropolar, with tri-radiate mark on proximal surface, on distal surface with worm-like and occasionally also with round papillae. Calyptrae mitrate, orange-brown, with hairs at base or throughout.

\section{Important characters}

Among the acrocarpous mosses, the genus Hedwigia has the unique combination of ecostate leaves with hyaline apices, papillose laminal cells, mostly ciliate perichaetial leaves and eperistomate, immersed capsules. Morphological characters used to separate individual species include: number of papillae per cell (one or several); branching pattern of papillae (peltate or not peltate, occasionally simple); shape of leaf apical cell (truncate, crowned with papillae or single-pointed); bending of leaf apices (straight or recurved in dry state); length of recurved leaf margin; length of hyaline hair points (measured in percents of leaf length); and spore size. One species, $H$. detonsa, differs from the rest species of the genus by the absence of cilia at the margin of its perichaetial leaves. This scarcity of distinctive morphological characters, their variability and difficulty to describe, e.g., shape and arrangement of papillae caused poor understanding of taxonomy within the genus.

\section{KEY TO IDENTIFICATION OF HEDWIGIA SPECIES IN

$$
\text { RUSSIA }
$$

1. Median laminal cells on abaxial side mainly with a single, branched, peltate papilla over each cell .... 2

- Median laminal cells on abaxial side with 2-4 branched, usually not peltate papillae over each cell.. 3

2. Leaf apices straight; median laminal cells strongly incrassate and porose ............. 1. H. czernyadjevae

- Leaf apices reflexed; median laminal cells slightly incrassate, not porose ........................ [H. stellata $]$

3. Plants small; leaves shortly acuminate, secund, with apices following leaf curvature; hyaline hair-points short, usually constituting less than $10 \%$ of leaf length 2. P. nemoralis

- Plants of medium size; leaves gradually narrowed to the apex or rather long acuminate, straight or secund; hyaline hair-points short to very long, usually constituting more than $10 \%$ of leaf length .......... 4

4. Leaves straight, $0.6-0.8 \mathrm{~mm}$ wide; hyaline hairpoints long, constituting 30-55\% of leaf length; leaf margins plane or narrowly recurved in proximal $1 / 5$ 1/2; papillae dense, with thick round branches, obscuring cell walls ............................ 5. H. emodica

- Leaves straight or secund, 0.85-1.1 mm wide; hyaline hair-points usually shorter, constituting (15-)23$27(-29) \%$ of leaf length; leaf margins recurved in proximal 1/4-3/4; papillae with narrow branches, irregularly arranged or forming longitudinal rows, not obscuring cell walls ....................................... 5

5. Leaf margins \pm widely recurved in lower $2 / 3-3 / 4$ of leaf; mid-leaf cells with more or less strongly sinuose and occasionally also porose longitudinal walls; spores (27.5-)30-35(-37.5) $\mu \mathrm{m}$...........4. H. ciliata

- Leaf margins narrowly recurved in lower $1 / 4-1 / 2$ of leaf; mid-leaf cells with straight or more or less sinuose, usually not porose longitudinal walls; spores 20-25(-28) $\mu \mathrm{m}$................................... 3. H. mollis

1. Hedwigia czernyadjevae Ignatova, Ignatov \& Fedosov sp. nova. Figs. 3-5, 20 C-D, 21 A, F, 22 A-B, 23 A-C.

Type: Russia, Siberia, Zabaikalsky Territory, Kyrinsky District, Sokhondinsky Nature Reserve, 49³7’N, $111^{\circ} 02^{\prime} \mathrm{E}, 1747 \mathrm{~m}$ alt., surroundings of kordon on Bukukun Creek bank, rock-field in Pinus sibirica forest, on rocks; 28.VIII.2011, Czernyadjeva 37-11 (holotype in LE!, isotypes issued as "Bryophyta Rossica et civitatum collimitanearum exsiccata, Komarov Botanical Institute, St.-Petersburg, Fasc. IX \#370, as H. stellata Hedenäs" were checked in MHA! and MW!, and we confirm their identity with the holotype). 
Diagnosis. The new species is most similar to Hedwigia detonsa (M. Howe) W.R. Buck \& D.H. Norris in unipapillose median leaf cells; strongly branched, peltate papillae; strongly thickened, straight, porose cell walls; spores ca. $25-27 \mu \mathrm{m}$ in diameter; pointed leaf apical cell; and non-recurved leaf apices in dry state. Their main distinctive character is a different structure of perichaetial leaves: strongly ciliate at margins in $H$. czernyadjevae and totally lacking cilia in $H$. detonsa. Distinctions from $H$. stellata, another species with mainly unipapillose median leaf cells, include straight leaf apices in dry state and porose longitudinal and transverse cell walls.

Etymology. The species name is given in honour of Irina V. Czernyadjeva, the bryologist from Komarov' Botanical Institute, St. Petersburg, Russia, a well-known researcher of the moss flora of the northern Siberia, Kamchatka and Transbaikalia, a collector of this species.

Description. Plants in easily disintegrating tufts, greyish green above, greyish brown below, dull. Stems ca. 5 $\mathrm{cm}$ long, repeatedly branched. Stem leaves spirally arranged, straight, rarely secund, with straight apices when dry, widely spreading when wet, $1.7-1.9 \times 0.7-0.8 \mathrm{~mm}$, with width to length ratio $0.35-0.41$, ovate and gradually narrowed to the apex or acuminate, concave; margins recurved at lower $3 / 4$ or to the base of hair-point; hyaline hair-points $(0.1-) 0.4-0.7 \mathrm{~mm}$ long, constituting (5-)23-43\% of leaf length; margins of hair-points entire or with few sharp teeth at distal portion, abaxial surface densely papillose, with simple and branched papillae, and also with dense, long spinulae; apical cell long, pointed, smooth or papillose at places, or with long spinulae near apex; median leaf cells (10-)12-19×10-13(-15) $\mu \mathrm{m}$, thick-walled, porose, with pores on longitudinal and transverse walls, on abaxial surface with single, large branched, peltate papilla in each cell, rarely with two papillae, on adaxial side with one similar in shape, but smaller papilla in each cell; cells in the middle of leaf base linear, 35-60 $\times 10-12 \mu \mathrm{m}$, porose, orange-brown, lowermost cells smooth, then gradually becoming papillose upwards, with several simple papillae per cell, rather abruptly transiting into unipapillose median leaf cells; basal marginal cells quadrate and transversely rectangular, with pores on transverse walls. Perichaetial leaves oblong, ca. $2.25 \times 0.75 \mathrm{~mm}$, hyaline hair-points ca. 0.5 $\mathrm{mm}$, cilia long, with 2-4 rows of cells in basal portion. Capsules obovoid, $1.2-1.4 \times 0.8-1.0 \mathrm{~mm}$, broadest slightly above the middle. Operculum lowly conical, with low central mammilla. Exothecial cells in the middle of urn rectangular or shortly rectangular, at urn mouth in several rows smaller and darker colored. Spores (23-)25$27.5 \mu \mathrm{m}$, on distal side with worm-like papillae. Calyptra strongly hairy throughout.

Distribution and ecology. In Zabaikasky Territory $H$. czernyadjevae was collected three times: in Sokhondinsky Nature Reserve, in Atsinkiy sanctuary and Kalarsky District on Udokan Mt. Range (at latitudes from 49 to $56^{\circ} 40^{\prime} \mathrm{N}$ ); all collections were made in upper forest belt, at 1460, 1745 and $1000 \mathrm{~m}$ a.s.l., in Pinus sibirica forest, on rocks in rock-fields and on rocks in larch forest. In Khabarovsk Territory it was found in the upper course of Levaya Bureya River in Bureinsky Nature Reserve, at ca. $51^{\circ} \mathrm{N}$, in upper forest and alpine belts, at $950-1700$ $\mathrm{m}$ a.s.1., on rock-fields. Collections in Yakutia were made on Suntar Khayata Mt. Ridge, at ca. $63^{\circ} \mathrm{N}$, in the lower course of Kyurbelyakh Creek, also in upper forest belt, on rock-field among open larch stands.

Specimens examined: ASIAN RUSSIA: Zabaikalsky Territory: Krasnochikoisky District, Atsa River basin (left tributary of Chikoy River), Atsinkiy sanctuary, upper course of Vankina Creek, 5009'43”N, 10909'27'”, 1466 m alt., 11.VIII.2011, Afonina 2911 (LE, MHA); Kalarsky District, Naminga Settlement, 56 $46^{\circ}$ 'N, $118^{\circ} 32^{\prime} \mathrm{E}, 1000 \mathrm{~m}$ alt., 11.VIII.1987, Kozhevnikova \& Filin s.n. (MW). Khabarovsk Territory: Verkhnebureinsky District, Bureinsky State Reserve: Kuraigagna Creek, $52^{\circ} 04^{\prime} \mathrm{N}, 134^{\circ} 35^{\prime} \mathrm{E}, 950 \mathrm{~m}$ alt., 15.VIII.1997, Iwatsuki 60522 and Ignatov 97-237 (MHA); Medvezh'e Lake, $52^{\circ} 05^{\prime} \mathrm{N}$, $135^{\circ} 01^{\prime} \mathrm{E}, 1600 \mathrm{~m}$ alt., 10.VIII.1997, Iwatsuki 60261 and Ignatov 97-237 (MHA). Republic of Sakha/Yakutia, Tomponsky District, right slope of Kyurbelyakh Creek, $63^{\circ} 07^{\prime} \mathrm{N}, 139^{\circ} 02^{\prime} \mathrm{E}$, $900 \mathrm{~m}$ alt., 9.VII.2011, Ignatov \& Ignatova 11-2234 (MHA).

Discussion and Differentiation. Superficially Hedwigia czernyadjevae is indistinct, although its narrowly attenuate hair-points with long apical cell look peculiar (see Fig. 3: A-B, D). When it was collected for the first time, it was identified as $H$. stellata (Ignatov et al., 2000) due to unipapillose laminal cells, each having one large, peltate papilla on both leaf surfaces and due to usually pointed apical leaf cell. However, these authors added a comment on the lack of recurved leaf apices in dry state in these plants; the latter character is quite characteristic for $H$. stellata (Hedenäs, 1994). One more difference noted by Ignatov et al. (2000) was its different ecology: in Europe H. stellata occurs in milder and warmer climate than $H$. ciliata, while in the Far Eastern region studied by Ignatov et al. (2000) ' H. stellata' grew in high mountains with deep permasfrost, while all collections of $H$. ciliata s.l. made in that area were restricted to lower elevations, although still with permafrost.

Molecular phylogenetic studies segregate $H$. czernyadjevae very clearly: separate analyses of each of three markers put its specimens in a separate clade, which received high support in the analyses of more variable ITS and nad5 (not shown), and as a clade in strict consensus tree of $t r n \mathrm{~L}-$ $\mathrm{F}$ (not shown). It is resolved in a maximally supported clade in the analyses of concatenated dataset (Fig. 1).

The intentional search of common morphological characters of these specimens revealed: (1) unipapillose laminal cells (Fig. 20 C); (2) peltate papillae (Fig. 3 F); (3) strongly porose laminal cells (Fig. 4 F); (4) conspicuously thin and long apical cell, which is usually singlepointed, smooth or lowly papillose, or occasionally has a sharp spinula near its end (Fig. 4 A-B); (5) perichaetial leaves with hyaline hair-points that have few robust, not 

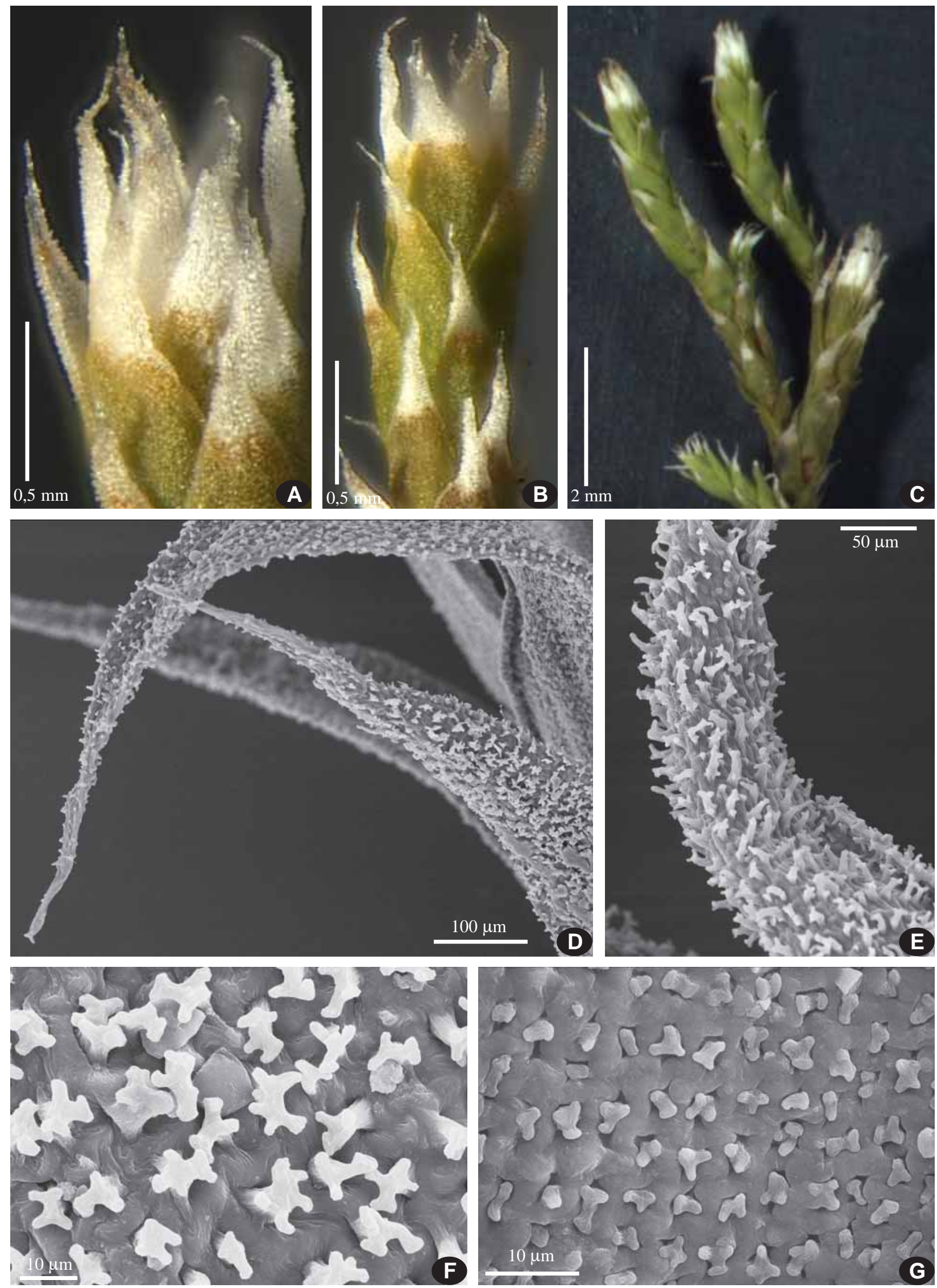

Fig. 3. Hedwigia czernyadjevae (from: Russia, Zabaikalsky Territory, Sokhondinsky Reserve, Czernyadjeva 37-11, MHA). AC: habit (SM); D-G (SEM): D: apical part of leaf; E: subapical part of leaf, dorsal view; F: papillae in mid-leaf on abaxial leaf surface; G: papillae in mid-leaf on adaxial leaf surface. 

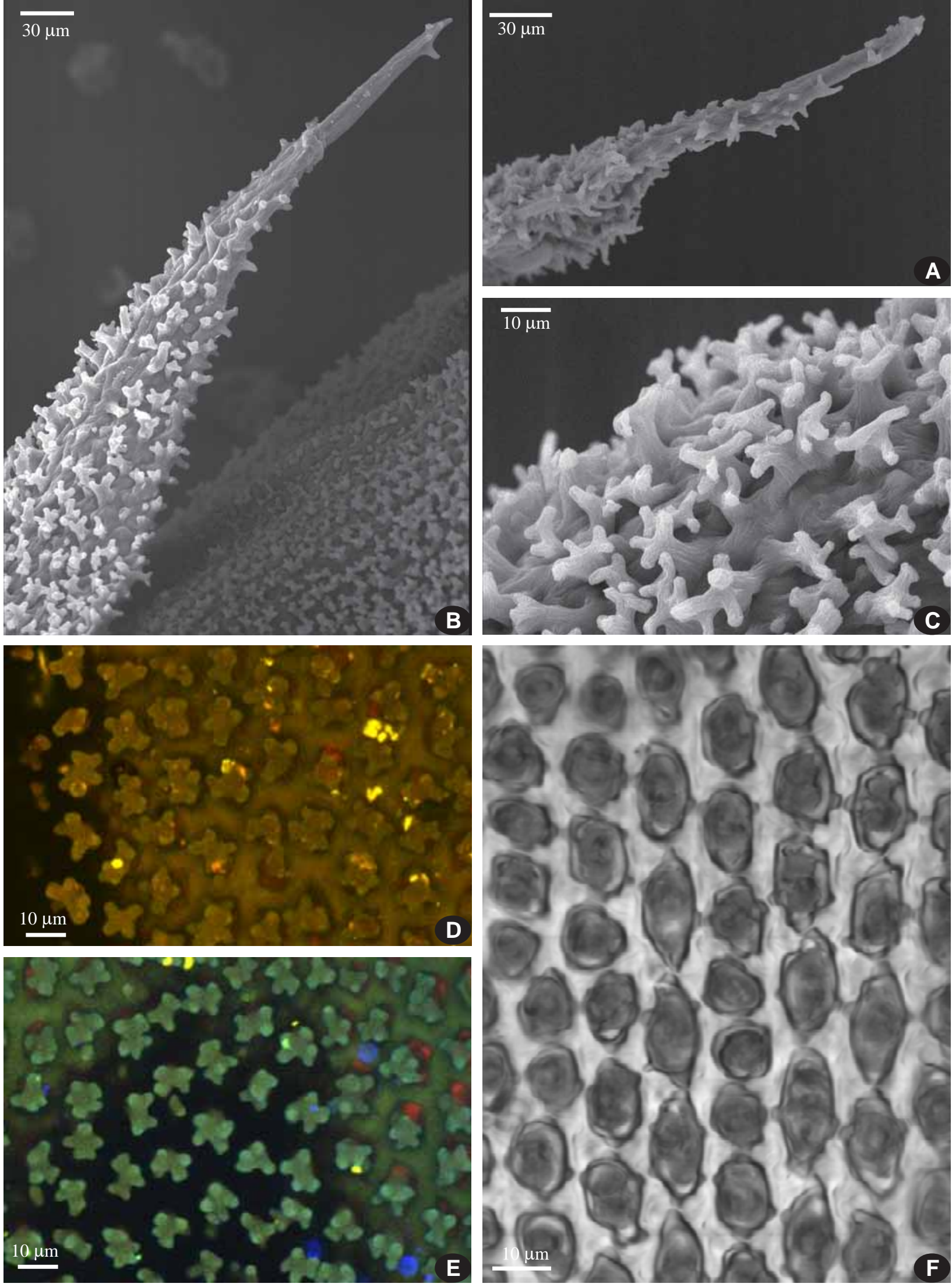

Fig. 4. Hedwigia czernyadjevae (from: Zabaikalsky Territory, Sokhondinsky Reserve, Czernyadjeva 37-11, MHA). A-C (SEM). A-B: leaf apical parts, showing long apical cell with few papillae or spinulae; C: papillae on abaxial side of hyaline hair-point; DE: papillae in mid-leaf on abaxial surface (LCSM). F: cell areolation in mid-leaf, showing thick-walled and porose cell walls (LCSM). 


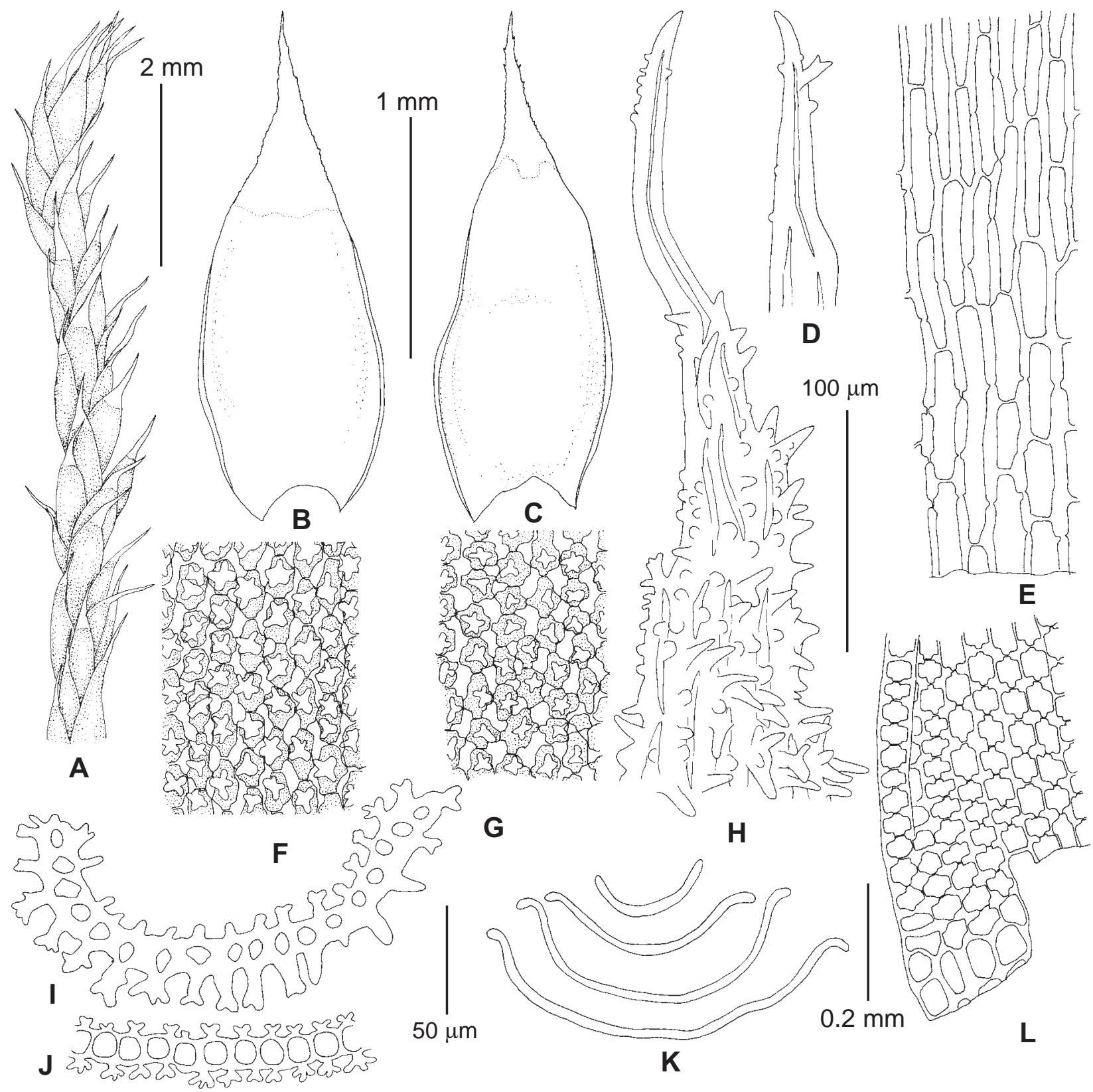

Fig. 5. Hedwigia czernyadjevae (from: Russia, Zabaikalsky Territory, Sokhondinsky Reserve, Czernyadjeva 37-11, MHA). A: habit, dry; B-C: stem leaves; D, H: leaf apical parts; E: cells in the middle of leaf base; F: median leaf cells from abaxial side; G: median leaf cells from adaxial side; I-K: leaf transverse sections; L: basal marginal cells. Scale bars: $2 \mathrm{~mm}$ for A; $1 \mathrm{~mm}$ for B-C, $0.2 \mathrm{~mm}$ for $\mathrm{K} ; 50 \mu \mathrm{m}$ for I-J; $100 \mu \mathrm{m}$ for $\mathrm{D}-\mathrm{H}, \mathrm{L}$.

especially flexuose ciliae (Fig. 21 A); (6) calyptra hairy throughout (Fig. $21 \mathrm{~F}$ ); (7) obovate capsules, broadest slightly above the middle (22 A-B); (8) medium-sized spores without distinct ridges (Fig. $23 \mathrm{~A}-\mathrm{C}$ ).

Characters $1 \& 2$ are shared with $H$. detonsa and $H$. stellata; $\mathbf{3}$ is common only with $H$. detonsa; $\mathbf{4}$ is somewhat similar to $H$. stellata; $\mathbf{5}$, the pattern of ciliae in perichaetial leaves in H. czernyadjevae looks peculiar (Fig. $21 \mathrm{~A}$ ); it resembles cilia in perichaetial leaves of $H$. striata (cf. Fig. 7: J-K in Buchbender et al., 2014); however this character might be subjective in evaluation, although further comparison seems promising; 6 seems to be unique for $H$. czernyadjevae, although the number of observa- tions are too few due to a limited number of collections with young sporophytes; 7 can be commented as the previous character; 8, spore sculpture differs from most other species (cf. Figs. 23-24), although SEM study included a limited number of samples.

Molecular phylogenetic analysis placed $H$. czernyadjevae next to $H$. detonsa, an endemic of western North America. Although the latter species is different from all Eurasian species in non-ciliate perichaetial leaves, its conspicuously incrassate and porose laminal cells are quite similar to $H$. czernyadjevae (Fig. 20 B), likely indicating their affinity. However, shape of papillae is different in these species (compare Figs. $20 \mathrm{~A}$ and $20 \mathrm{C}$ ). 
Hedwigia stellata differs from $H$. czernyadjevae primarily in reflexed leaf apices (cf. Fig. 16 A) and less incrassate laminal cells. It was described from Sweden, but found in other parts of Europe (especially with oceanic climate), Western North America and in Sino-Himalayan region (Dalton et al., 2013). However, only few European specimens were tested with molecular markers, showing close affinity and possible introgression to $H$. ciliata, which will be discussed under that species.

Variation. Plants from northern populations in Yakutia differ from those in Transbaikalia and Khabarovsk Territory in shorter hair-points, constituting only 5-9\% of leaf length.

2. Hedwigia nemoralis Ignatova, Ignatov \& Fedosov sp. nova. Figs. 6-9, 20 E-F, 21 B, 22 D, 23 D-I.

Type: Russia, Primorsky Territory, Olga District, waterfall on Milogradovka Creek, $43^{\circ} 27.5^{\prime} \mathrm{N}, 134^{\circ} 19.3^{\prime} \mathrm{E}$, 370 m alt., dry cliffs near waterfall, 21.VIII.2007, Ignatov 07-324 (holotype MHA!, isotypes MW!, LE!).

Diagnosis. This species is similar to Hedwigia ciliata in pluripapillose median leaf cells and truncate apical cell; it differs in smaller size of plants, shortly acuminate leaves, often very short hyaline hair-points, few ciliae in perichaetial leaves, median laminal cells with esinuose or slightly sinuose walls and smaller papillae, smaller spores, (17.5-)20-22.5(-25) $\mu \mathrm{m}$ vs. (27.5-)30-35(-37.5) $\mu \mathrm{m}$ in $H$. ciliata and distinct flexuose-ridged spore ornamentation. Spore characters are common with two others species, $H$. mollis and $H$. emodica; $H$ nemoralis differs from them in shorter hyaline hair-points and weakly ciliate perichaetial leaves.

Etymology. The name refers to the species distribution in southern regions, mostly in zone of broad-leaved deciduous forest, or the nemoral zone.

Description. Plants in compact tufts, green or greyish green above, occasionally with yellowish tint, brownish below, dull. Stems $1.5-5 \mathrm{~cm}$ long, repeatedly branched. Stem leaves spirally arranged, appressed when dry, usually secund, with short apices following leaf curvature, widely spreading when wet, $1.25-1.5(-1.8) \times 0.7-$ $0.9 \mathrm{~mm}$, with width to length ratio $0.45-0.55$, ovate-triangular, shortly acuminate, canaliculate in distal portion, concave in proximal part; margins narrowly recurved at lower $1 / 4-2 / 3$, in leaves from upper part of shoots to the base of hair-point; hyaline hair-points $0.05-0.2(-0.3) \mathrm{mm}$ long, constituting (5-)8-9(-18)\% of leaf length; margins of hair-points sharply denticulate, abaxial surface with simple papillae and spinulae, distal portion of hairpoint weakly papillose to smooth, apical cell short, truncate or occasionally pointed, smooth or crowned with papillae; median leaf cells $9-15(-20) \times 8-13(-15) \mu \mathrm{m}$, thick-walled, non-porose, with straight or weakly sinuose walls, on abaxial surface with 2-3 strongly branched papillae with long, narrow branches in each cell; on adaxial side with 1-2(-3) simple or weakly branched papillae in each cell; cells in the middle of leaf base linear,
$25-75 \times 8-10 \mu \mathrm{m}$, porose, orange-brown, lowermost cells smooth, then gradually becoming papillose upwards, with several simple papillae per cell, rather abruptly transiting into median leaf cells; basal marginal cells quadrate and shortly rectangular, occasionally with pores on transverse walls. Perichaetial leaves narrow, oblong, ca. $2.9 \times 0.5 \mathrm{~mm}$, hyaline hair-points ca. $0.25 \mathrm{~mm}$, cilia comparatively few, easily broken, inconspicuous in perichaetia; when remained intact in innermost perichaetial leaves, there are several long cilia below narrow acumen. Capsules cup-like, $1-1.1 \times 0.9 \mathrm{~mm}$, widest slightly below urn mouth. Opercula low conical, with low central mammilla. Exothecial cells in the middle of urn rectangular or short rectangular, at urn mouth in several rows smaller and darker colored. Spores (17.5-)20-22.5(-25) $\mu \mathrm{m}$, on distal side with labyrinth-like papillae. Calyptra with few hairs at base.

Distribution and ecology. In the Caucasus, H. nemoralis is restricted to the Black Sea coastal area; it is known from a comparatively humid places in Sochi District in Russia and from Adjaria in Georgia, but absent in dryer place in Novorossijsk District (Utrish Nature Reserve). It was collected on boulders in beech forest, at $90 \mathrm{~m}$ a.s.l. and on dry stone in broadleaved Colchis forest at $350 \mathrm{~m}$ a.s.1. In Zabaikalsky Territory it grew in forest zone, at ca. $950 \mathrm{~m}$ a.s.l., on rocks on slope. In Primorsky Territory $H$. nemoralis was collected at low altitude, ca. $370 \mathrm{~m}$ a.s.l., on dry cliff near waterfall. Northernmost locality of the species in Kaluga Province (ca. $54^{\circ} \mathrm{N}$ ) is known as a place where some locally rare vascular plants (Polystichum braunii) and mosses (Pohlia elongata, Schistostega pennata) were found; H. nemoralis grew there on sandstone outcrops. In North America, the species was collected in Hickory Canyons Natural Area at $300 \mathrm{~m}$ a.s.l.; however, label information is scarce. Few other specimens from U.S.A. (Maryland and Virginia) deposited in MHA also likely belong to H. nemoralis; its distribution in this region needs further study.

Specimens examined: EUROPEAN RUSSIA: Krasnodar Territory, Sochi District, NW of Lazarevskoe, Kuapse Creek, 435'⒍8'N, 39¹9'16.2”'E, 90 m alt., 29.I.2012, Ignatov \& Ignatova 12-89 (MHA). Kaluga Province, Kozelsk District, 'Ugra' National Park, Chertovo Gorodishche, $54^{\circ} 05^{\prime} \mathrm{N}, 36^{\circ} \mathrm{E}$, 24.IX.2004, Teleganova 04-1 (MHA). ASIAN RUSSIA: Zabaikalsky Territory, Krasnochikoisky District, Yugal Creek tributary of Chikoy River, $50^{\circ} 15^{\prime} 56^{\prime \prime} \mathrm{N}, 109^{\circ} 05^{\prime} 30^{\prime \prime} \mathrm{E}, 953 \mathrm{~m}$ alt., 12.VIII.2011, Afonina 3411 (LE, MHA). GEORGIA: Adjaria, Mtirala National Park, Chakvistavi River valley near

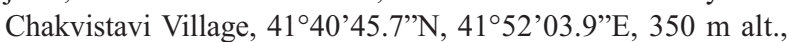
11.V.2013, Bakalin G-11-60-13 (MHA). NORTH AMERICA: U.S.A.: Missouri, Sainte Genevieve Co., Hickory Canyons Natural Area, $37^{\circ} 52^{\prime} 35^{\prime} \mathrm{N}, 90^{\circ} 18^{\prime} 18^{\prime}$ 'W, $300 \mathrm{~m}$ alt., 26.X.2014, Bakalin \&Brinda US-41-37-14 (VBGI, duplicate in MHA); Maryland, river Potomac, Great Falls, 8.II.2008, Tsegmed s.n. (MHA); Virginia, Great Wall mountain ridge W of Blacksburg, $37^{\circ} 20^{\prime} \mathrm{N}, 80^{\circ} 45^{\prime} \mathrm{W}, 2$.XII.1995, Ignatov s.n. (MHA).

Discussion and Differentiation. At the first glance Hedwigia nemoralis can be considered just as a small 

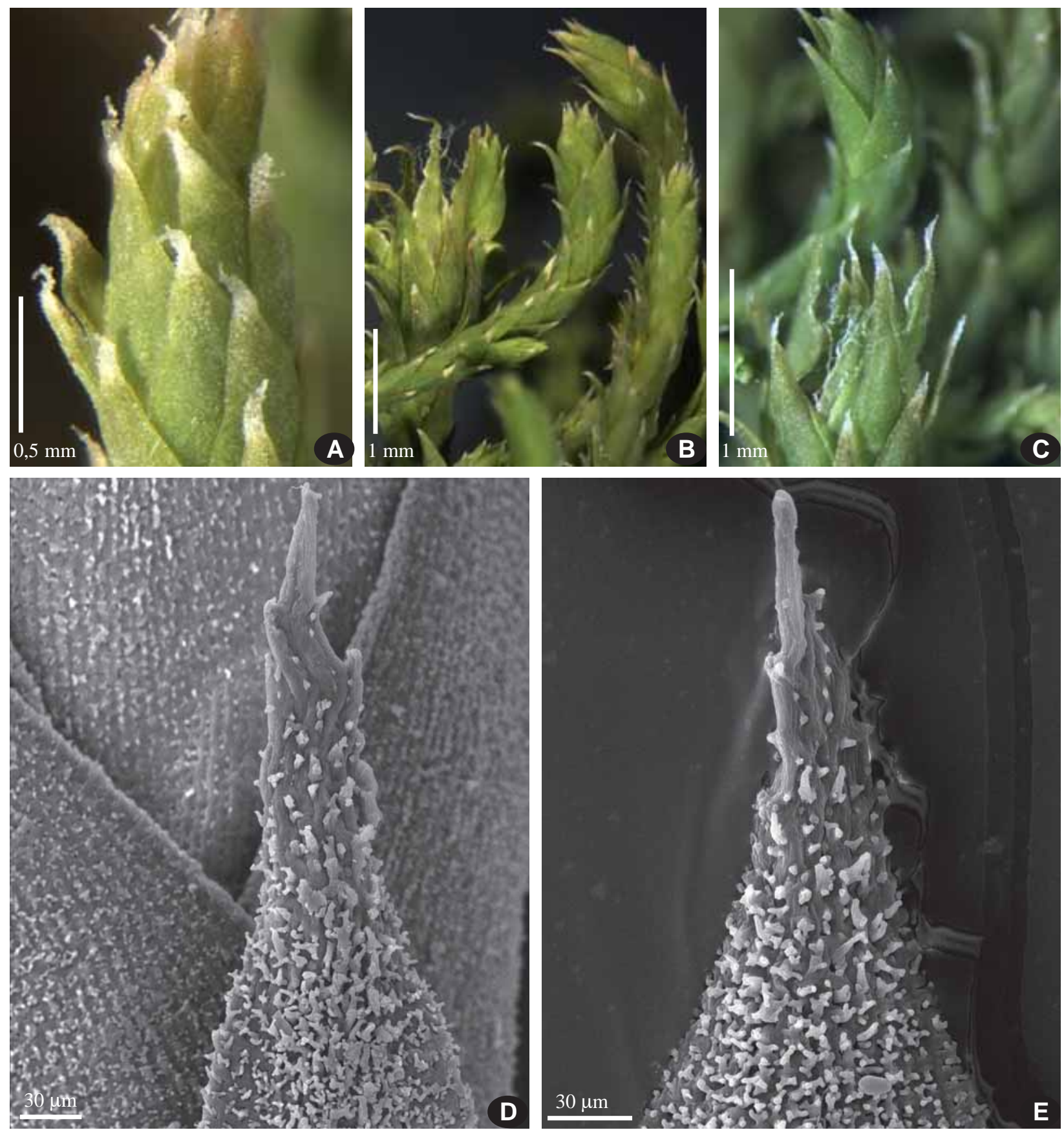

E
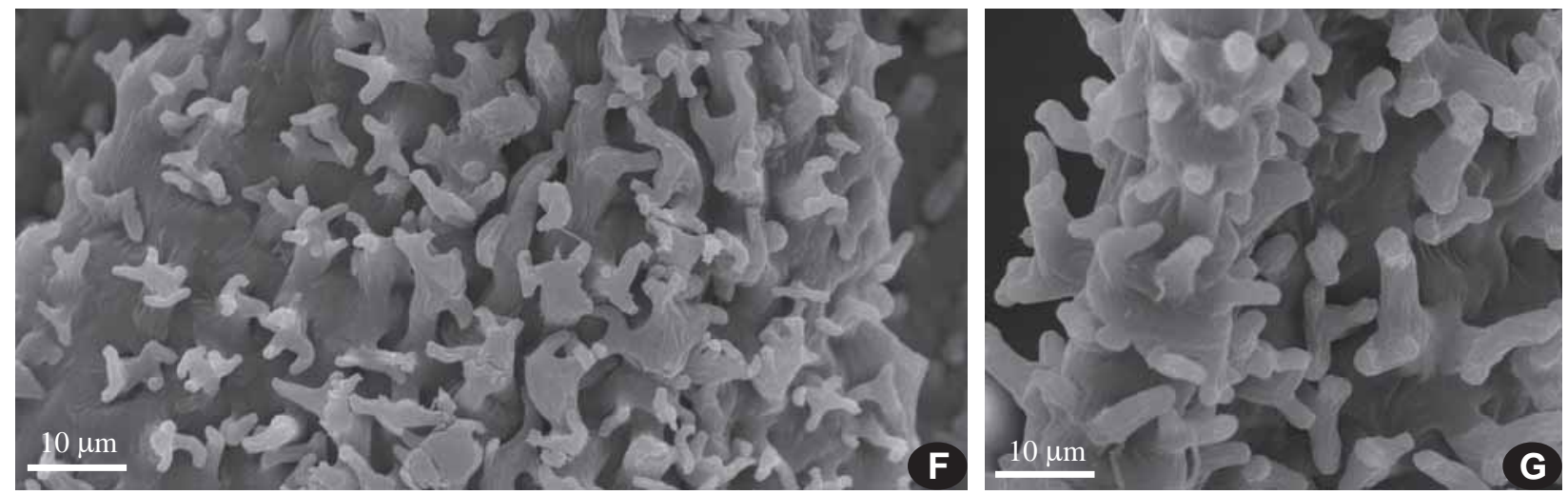

Fig. 6. Hedwigia nemoralis (A, F-G - from: Primorsky Territory, Ignatov 07-324,MHA; B-C - from: Krasnodar Territory, Ignatov \& Ignatova 12-89, MHA; D - from: Zabaikalsky Territory, Afonina 3411, MHA; E - from: Georgia, Adjaria, Bakalin G11-60-13, MHA). A-C: habit (SM); D-G (SEM). D-E: apical parts of leaves; F-G: subapical parts of leaves, abaxial view. 

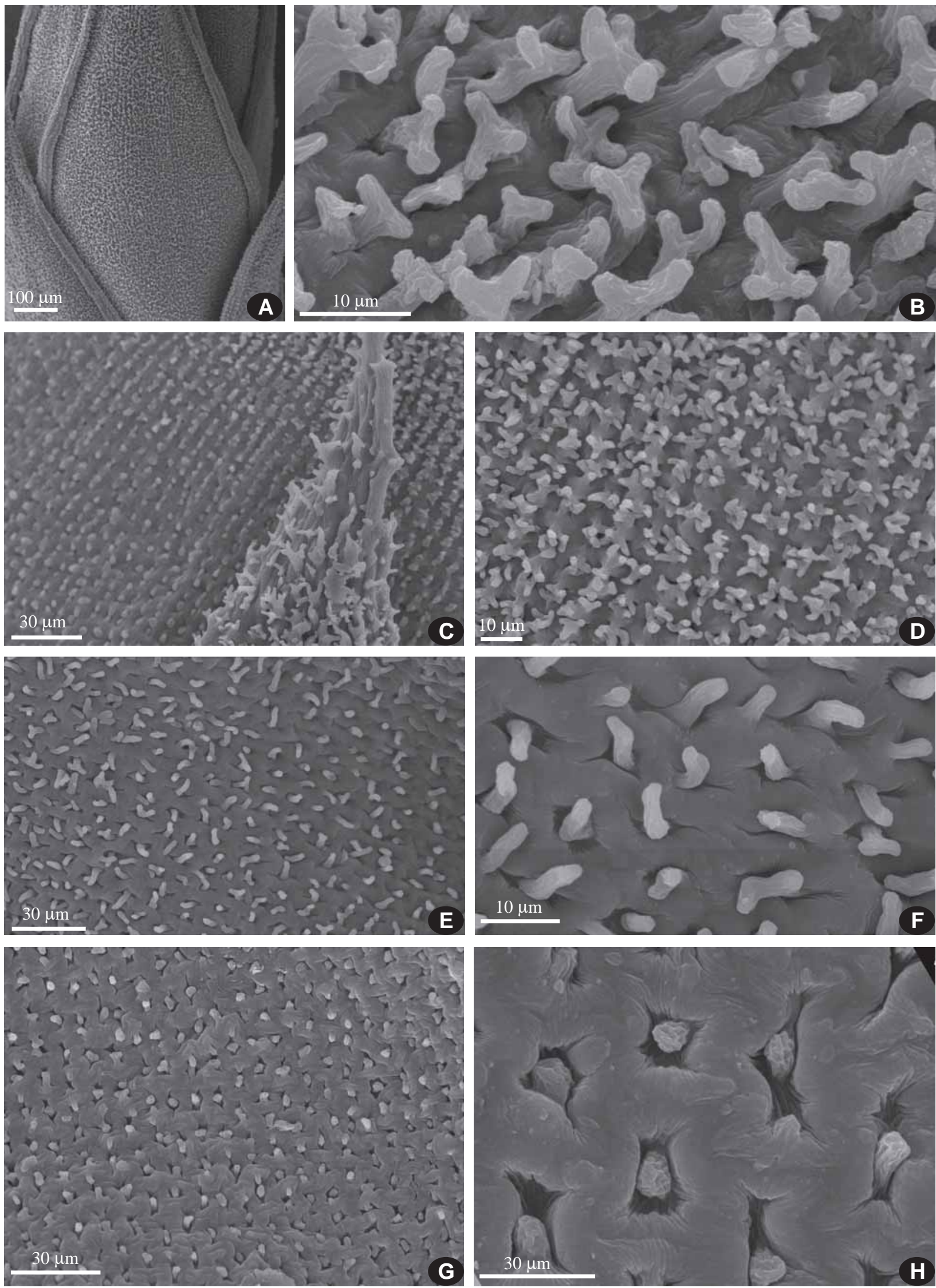

Fig. 7. Hedwigia nemoralis (A, E, F - from: Georgia, Bakalin G-11-60-13, MHA; B - from: Zabaikalsky Territory, Afonina 3411, MHA; C, D - from: Primorsky Territory, Ignatov 07-324, MHA; G, H - from: Krasnodar Territory, Ignatov \& Ignatova 12-89, MHA). A-H (SEM). A, C: leaf, abaxial view; B, D: papillae in mid-leaf on abaxial surface; E-H: papillae in mid-leaf on adaxial surface. 

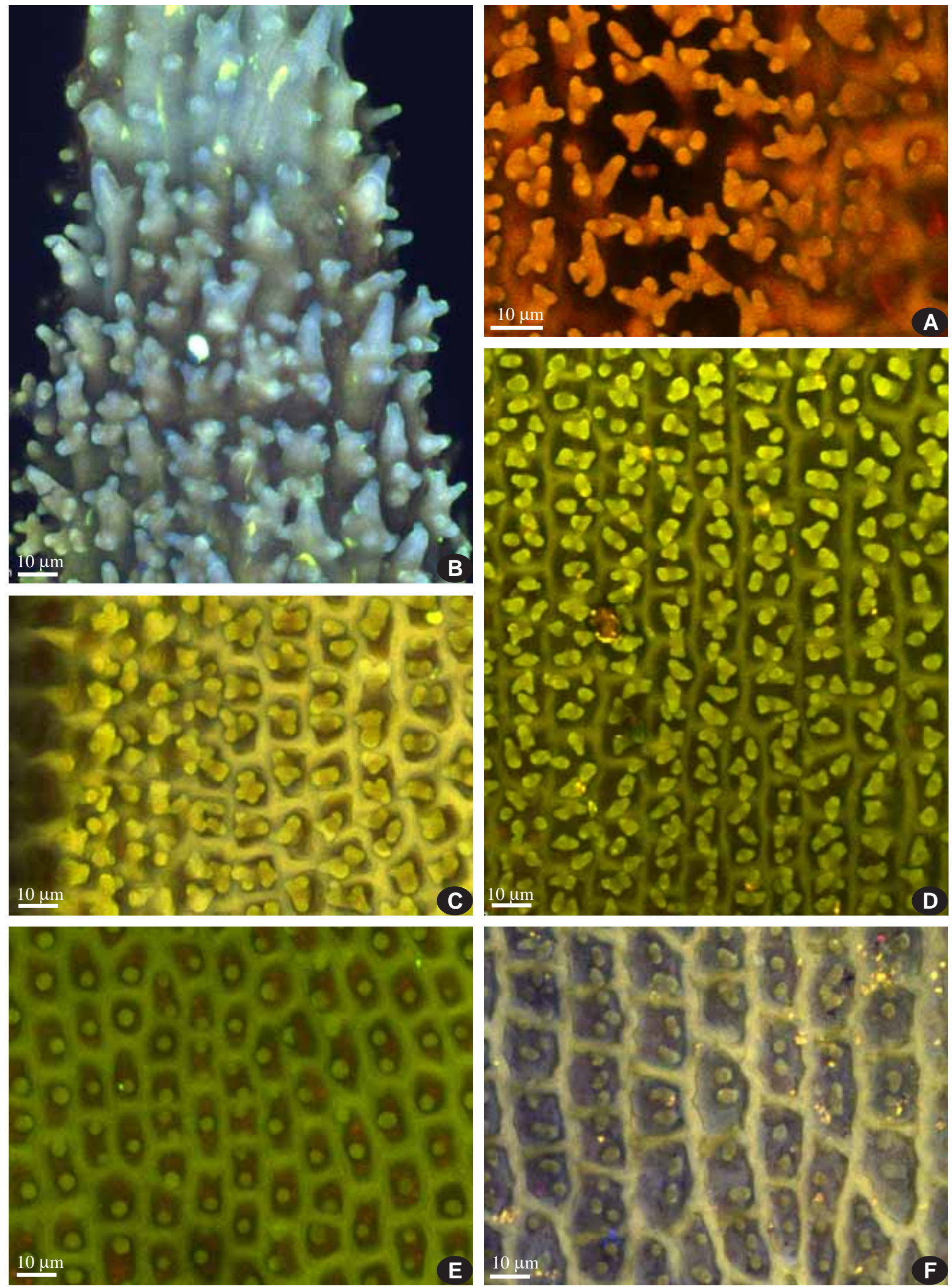

Fig. 8. Hedwigia nemoralis (A-C, E-F - from: Primorsky Territory, Ignatov 07-324, MHA; D - from: Krasnodar Territory, Ignatov \& Ignatova 12-89, MHA). A-F (LCSM). A, B: lower part of hair-point, abaxial side; C-D: papillae in mid-leaf on abaxial surface; E-F: papillae in mid-leaf on adaxial surface. 


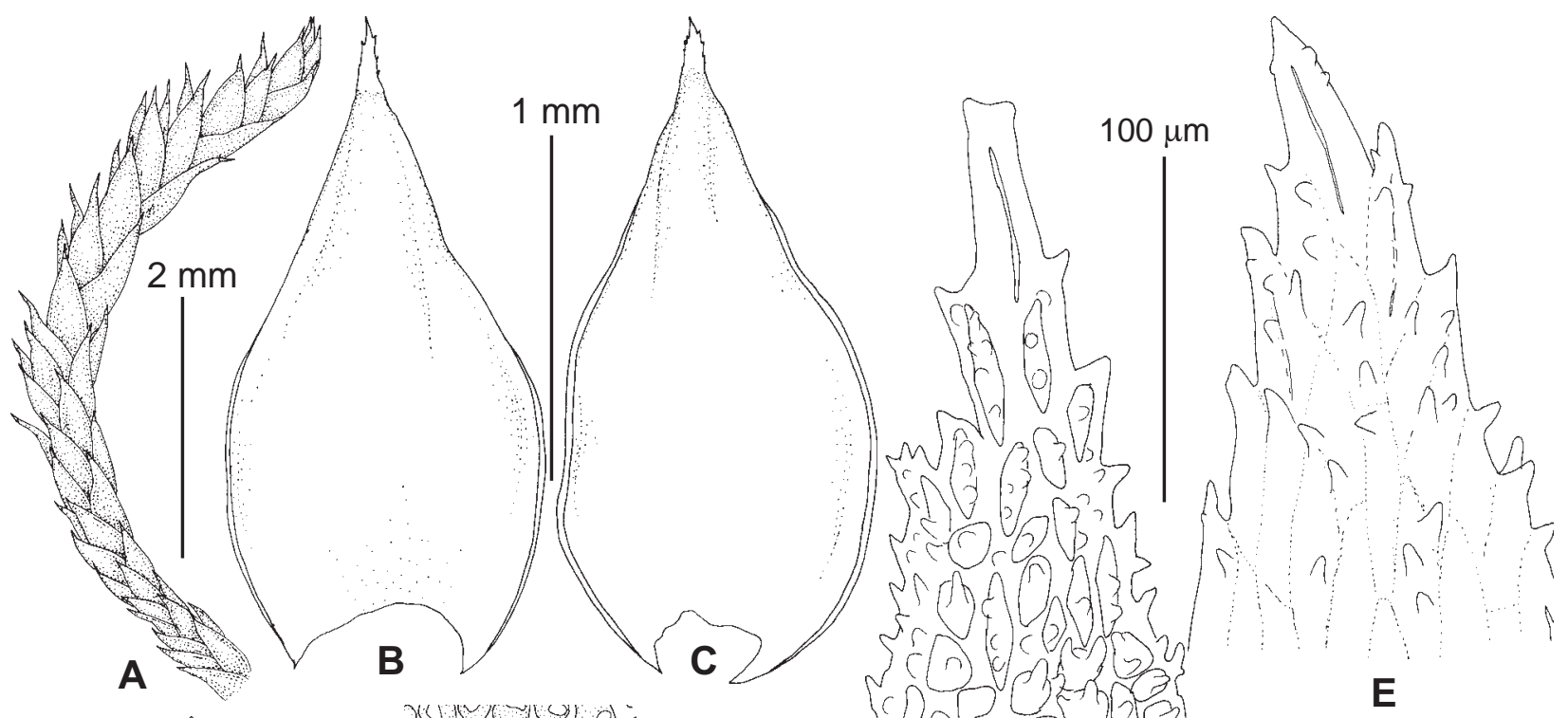

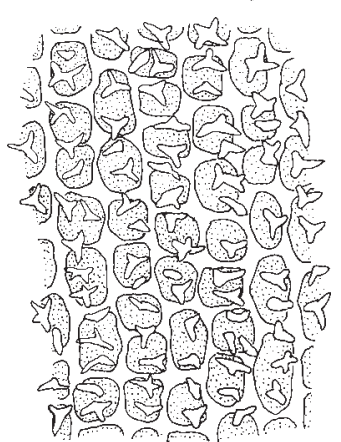

$\mathbf{F}$

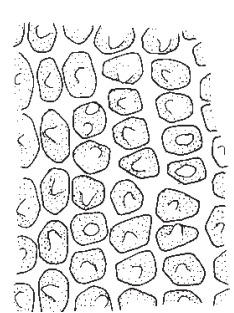

$\mathbf{J}$

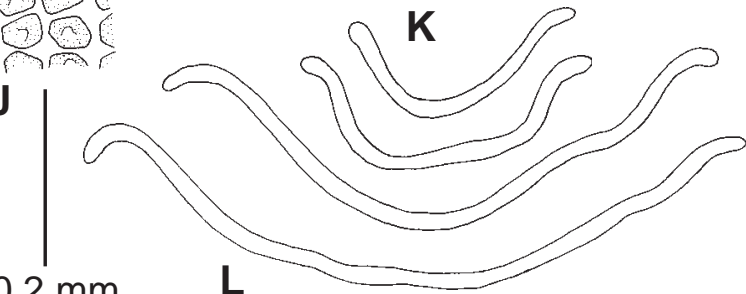

$0.2 \mathrm{~mm}$

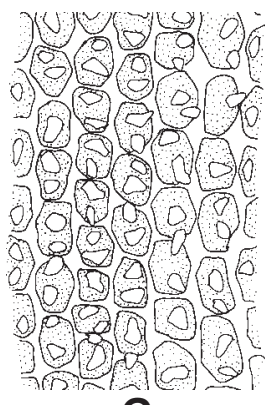

G

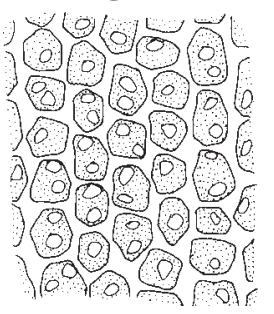

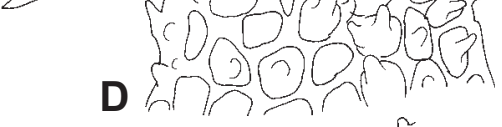
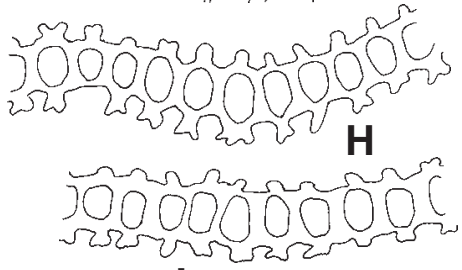

I
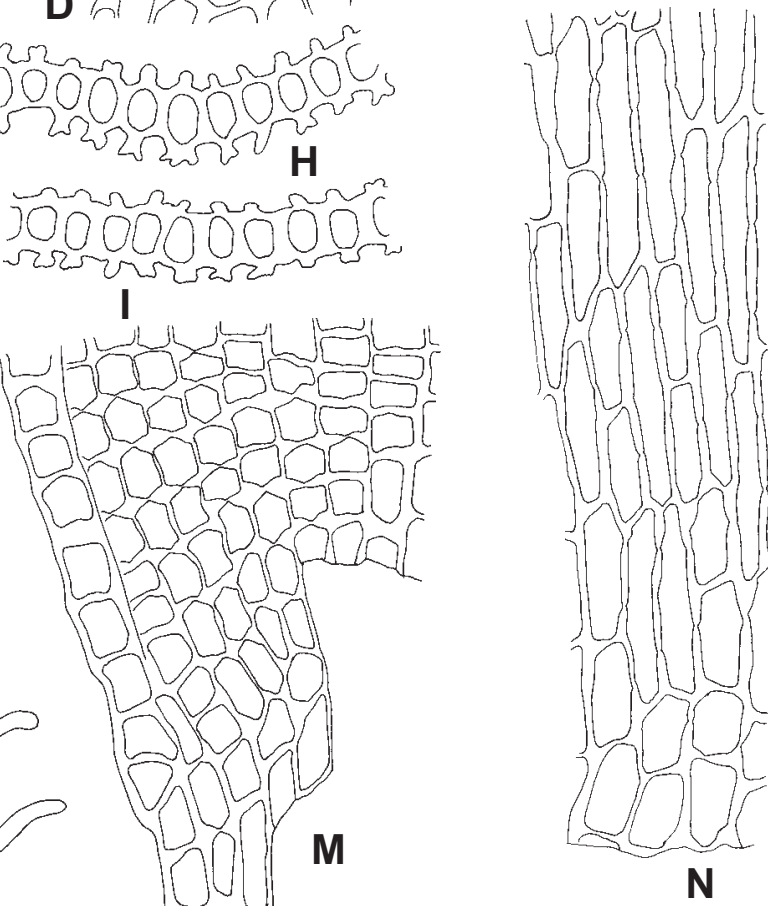

Fig. 9. Hedwigia nemoralis (A-F, H-J, L-N - from: Russia, Primorsky Territory, Milogradovka, Ignatov 07-324, MHA; G, K from: Russia, Krasnodar Territory, Lazarevskoe, Ignatov \& Ignatova 12-89, MHA). A: habit, dry; B-C: stem leaves; D-E: leaf apical parts; F-G: median leaf cells from abaxial side; H-I, L: leaf transverse sections; J-K: median leaf cells from adaxial side; M: basal marginal cells; $\mathrm{N}$ : cells in the middle of leaf base. Scale bars: $2 \mathrm{~mm}$ for A; $1 \mathrm{~mm}$ for B-C, $0.2 \mathrm{~mm}$ for L, $100 \mu \mathrm{m}$ for D-K, M-N.

Hedwigia, with short hyaline hair-points, resulting in an overall green color of plants. Its high support in molecular phylogenetic analysis was rather unexpected. Interestingly, all specimens of this taxon have a very southern distribution in Russia; it was also found in Georgia near the Black Sea coast. One sample from North America selected because of its superficial resemblance also appeared to be molecularly identical with the Eurasian specimens.

Additional observation on plant morphology revealed the following common characters of H. nemora- lis: (1) comparatively small size of plants; (2) usually secund, shortly acuminate and shortly hair-pointed leaves; (3) narrowly recurved leaf margin (Fig. 7 A); (4) mainly esinuose median laminal cells with rather dense, strongly branched papillae with long, narrow branches on abaxial leaf surface (Figs. 7 B, D; 8 A, D; 20 E-F); (5) simple long papillae on adaxial leaf surface at leaf middle (Fig. 7 E-H); (6) weakly ciliate perichaetial leaves (Fig. 21 B); (7) small spores with distinct, high, flexuose ridges (Fig. 23 D-I). 
Hedwigia ciliata from NW European Russia (as it is described below) is easily differentiated from $H$. nemoralis by its sinuose longitudinal walls of the mid-leaf cells, longer hair-points and, especially, considerably larger spores (mostly $30-35$ vs. $20-25 \mu \mathrm{m}$ ), that also lack a flexuoseridged ornamentation. Hedwigia emodica (as it is understood here) is the least likely to be confused with $H$. nemoralis due to contrastingly longer hair-points (compare Fig. 6 A-C and Fig 17 A-D); in addition, its papillae are very dense, with thick round branches, and the ornamentation of its spore surface differs in the presence of round papillae instead of ridges or as admixture to comparatively short ridges (Fig. $24 \mathrm{I}-\mathrm{L}$ ). For comparison with the morphologically closest $H$. mollis, see comments under that species.

Variation. Plants from the Caucasus have the shortest hair-points, $0.05-0.1 \mathrm{~mm}$ (3-6\% of leaf length), while in plants from Primorsky Territory and especially from Transbaikalia the hair-points are slightly longer, $0.1-0.3$ $\mathrm{mm}(8-18 \%$ of leaf length). A specimen from Transbaikalia differs also in having slightly larger cells with more sinuose longitudinal walls. The cell walls are slightly thinner in the Caucasian specimens than in Far Eastern ones (Fig. 9 F-G). A specimen from Kaluga Province has the largest leaves, ca. $1.8 \mathrm{~mm}$ long. A specimen from Krasnodar Territory also differs from the rest studied specimens in sparser and less branched papillae in mid-leaf on the abaxial side.

3. Hedwigia mollis Ignatova, Ignatov \& Fedosov sp. nova. Figs.10-12; 20 G-H; $21 \mathrm{C}, \mathrm{G}, \mathrm{I} ; 22 \mathrm{E} ; 23 \mathrm{~J}-\mathrm{O}$.

Type: Russia, Orenburg Province, Kuvandyk District, Orenburgsky Nature Reserve, Aituarskaya steppe, $51^{\circ} 07^{\prime} \mathrm{N}, 57^{\circ} 43^{\prime} \mathrm{E}, 222 \mathrm{~m}$ alt., bank of Ural River, cliffs, I.VI.2004, Spirina \& Zolotov s.n. (holotype MHA!, isotypes MW!, LE!).

Diagnosis. This species is superficially similar to Hedwigia ciliata and also has pluripapillose median leaf cells; it differs in narrowly and shortly recurved leaf margins; smaller spores, 20-25(-28) $\mu \mathrm{m}$ vs. (27.5-)30-35 $(-37.5) \mu \mathrm{m}$; and smaller papillae. The differences from $H$. nemoralis include larger size of plants; larger leaves, $0.9-1.1 \mathrm{~mm}$ wide vs. $0.7-0.8 \mathrm{~mm}$ wide in $H$. nemoralis; longer hair-points, $0.3-0.5 \mathrm{~mm}$ vs. $0.1-0.2(-0.3) \mathrm{mm}$ long; and strongly ciliate perichaetial leaves. H. emodica differs primarily by dense papillosity over cells, making areolation inconspicuous, and longer hair-points.

Etymology. The species name refers to a soft appearance of plants.

Description. Plants in loose or compact tufts, dark greyish green above, brownish below, dull. Stems $1.5-3 \mathrm{~cm}$ long, strongly branched. Stem leaves spirally arranged, straight, rarely secund, occasionally with erect-spreading apices when dry, widely spreading when wet, 1.5$2.0 \times 0.85-1.1 \mathrm{~mm}$, with width to length ratio $0.40-0.57$, ovate, gradually narrowed to the apex or acuminate, concave; margins narrowly recurved at lower $1 / 4-1 / 2$; hyaline hair-points $0.3-0.5 \mathrm{~mm}$ long, constituting (17-)23-
$27(-29) \%$ of leaf length; margins of hair-points denticulate, abaxial surface with simple papillae and spinulae, distal portion of hair-points weakly papillose to smooth, apical cell short, truncate or, rarely, single-pointed, finely papillose or smooth; median leaf cells (11-)15-23(-28) $\times 11-14(-15) \mu \mathrm{m}$, with moderately thickened, straight or weakly sinuose, non-porose walls, on abaxial surface with 2-3(-4) papillae in each cells, papillae small, strongly branched, often compact, not overlapping longitudinal walls; on adaxial side with 2-3 smaller, otherwise similar papillae in each cell; cells in the middle of leaf base linear, 50-75×(10-)12-14 $\mu \mathrm{m}$, porose, orange-brown, lowermost cells smooth, then gradually becoming papillose upwards, with several simple papillae per cell, rather abruptly transiting into median leaf cells; basal marginal cells quadrate and transversely rectangular, with pores on transverse walls. Perichaetial leaves oblong, 2.25-2.8×0.6-0.8 mm, hyaline hair-points $0.8-1.0 \mathrm{~mm}$, cilia numerous, conspicuous in perichaetia. Capsules obovoid, $1-1.2 \times 0.8-1.0 \mathrm{~mm}$. Opercula low conical, with low central mammilla. Exothecial cells in the middle of urn rectangular or short rectangular, at urn mouth in several rows smaller and darker colored. Spores 20-25(-28) $\mu \mathrm{m}$, on distal side with wormlike and round papillae. Calyptrae with few hairs at base.

Distribution and ecology. Hedwigia mollis grows in mesic to xeric habitats, both open and shaded, sometimes in generally calcareous areas. It is presently known mainly from European Russia, including south of Murmansk Province (surroundings of Kandalaksha at the White Sea shore), Karelia, several provinces south of Moscow (Tula, Kursk, Lipetzk), Karachay-Cherkessia and KabardinoBalkaria in the Caucasus, where it grows in forest and subalpine zones. It is also sporadic in South Urals, from steppe zone in Orenburg Province (type locality) to the forest zone of Bashkortostan. In Orenburgsky Nature Reserve in was collected at $220 \mathrm{~m}$ a.s.1., on cliffs at the bank of Ural River, while in Bashkortostan it grew on limestone rock outcrops in pine forest. It was also found in Altai Mts, mainly in mesic forests at the shore of Teletzkoe Lake; sequenced specimen from Altai was collected at $470 \mathrm{~m}$ a.s.1., in rather xeric locality in Chulyshman River valley, on rocks in dense birch forest.

Specimens examined: EUROPEAN RUSSIA: Murmansk Province, 5-7 km eastward of Kandalaksha, ca. $67^{\circ} 10^{\prime} \mathrm{N}$, 32³0'E, 10 m alt., 4.VIII.1998, Ignatov s.n. (MHA). Republic of Karelia, Prionezhsky District, Botanical Garden of Petrozavodsk University, 6351'N, 34²7'E, 13.IV.1997, Bakalin \& Bakalina, Bryophyta Karelica Exsiccata №33 (MHA). Tula Province, Efremov District, 'Paporotnikovoe', 11.VIII.1983, Popova s.n. (MHA). Kursk Province, Zheleznogorsk District, Volkovo Village, 30.VII.2004, Poluyanov 101I (MHA). Lipetzk Province, Stegalovka Settl., 'Kamennyj Les', 7.VI.1986, Popova s.n. (MHA). Karachay-Cherkessia, Teberda Nature Reserve, upper course of Malaya Khatipara Creek, $43^{\circ} 26.5^{\prime} \mathrm{N}, 41^{\circ} 41.5^{\prime} \mathrm{E}, 2550 \mathrm{~m}$ alt., 2.IX.2005, Ignatov \& Ignatova 05-3103 (MHA). Bashkortostan Republic, Ishimbaisky District, Makarovskoe Forestry, right bank of Uryuk River, 17.VI.2001, Zolotov 11-23 (MHA). ASIAN RUSSIA: Altai Re- 

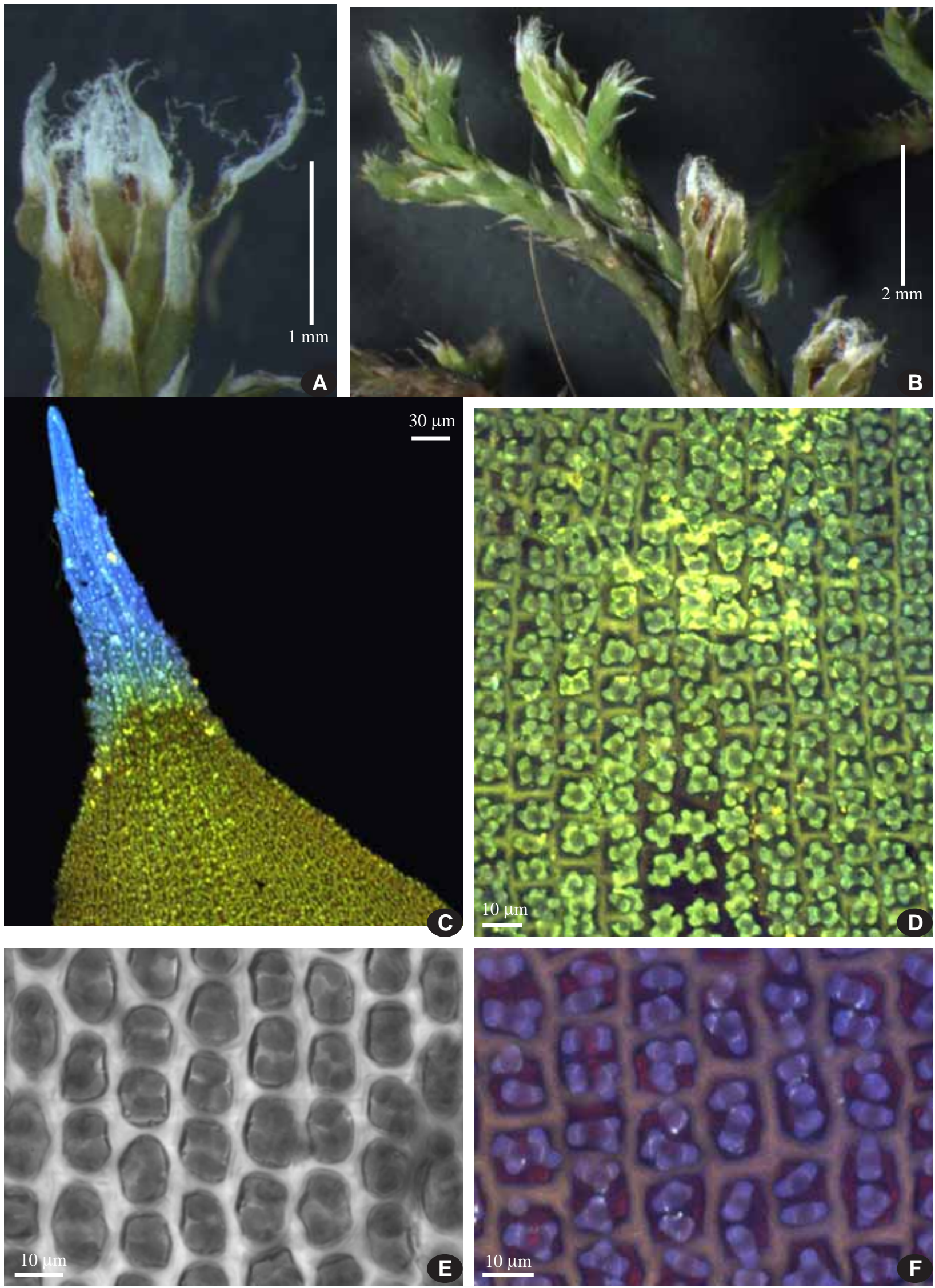

Fig. 10. Hedwigia mollis (A-B, E - from: Altai, Ignatov \& Ignatova 12-520, MHA; C-D, F - from: Orenburg Province, 1.VI.2004, Spirina \& Zolotov s.n., MHA). A-B: habit (SM); C-F (LSCM). C: apical part of leaf; D: subapical part of leaf on abaxial side; E: lamina areolation; F: papillae in mid-leaf on adaxial leaf surface. 

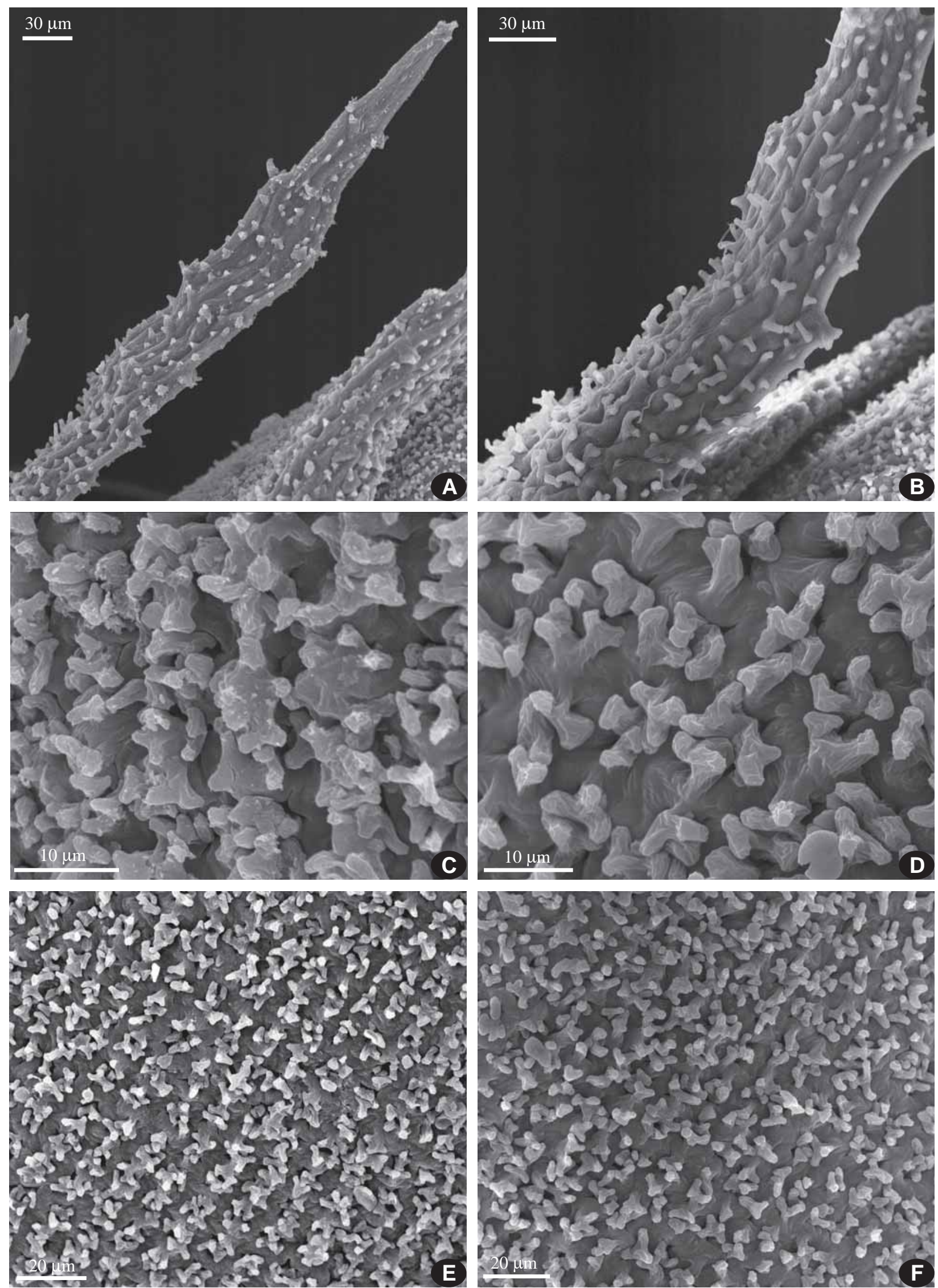

Fig. 11. Hedwigia mollis (A, C, E - from: Orenburg Province, 1.VI.2004, Spirina \& Ziolotov s.n., MHA; B, D, F - from: Karachay-Cherkessia, Ignatov \& Ignatova 05-3103, MHA). A-F (SEM). A-B: apical parts of leaves; C-F: papillae in mid-leaf on abaxial leaf surface. 


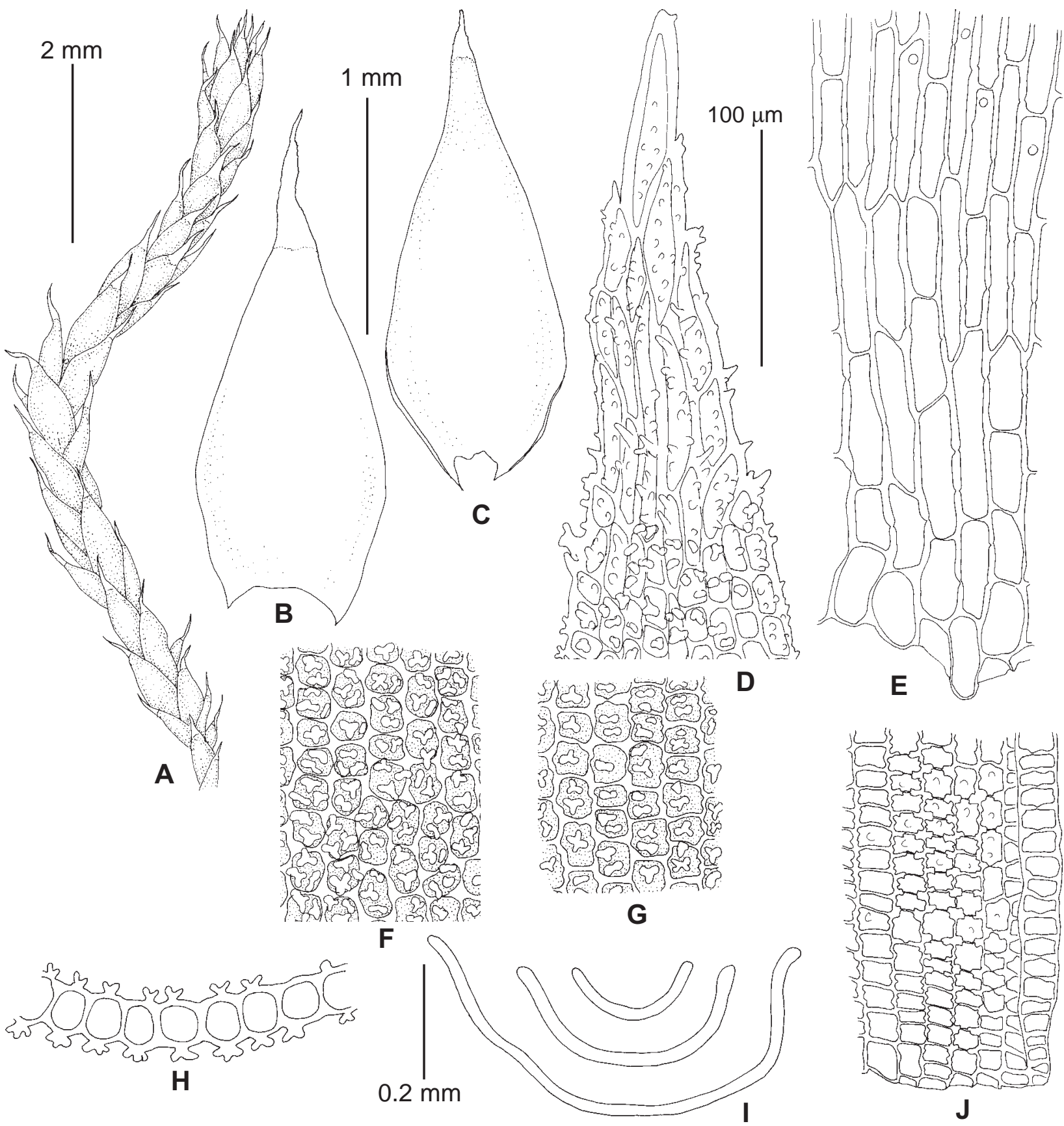

Fig. 12. Hedwigia mollis (from: Russia, Orenburg Province, 1.VI.2004, Spirina \& Zolotov s.n., MHA). A: habit, dry; B-C: stem leaves; D: leaf apical part; E: cells in the middle of leaf base; F: median leaf cells from abaxial side; G: median leaf cells from adaxial side; H-I: leaf transverse sections; J: basal marginal cells. Scale bars: $2 \mathrm{~mm}$ for A; $1 \mathrm{~mm}$ for B-C; $0.2 \mathrm{~mm}$ for I, $100 \mu \mathrm{m}$ for D-H, J.

public, Ulagan District, Chulyshman River 6 km upstream its mouth, $51^{\circ} 18^{\prime} \mathrm{N}, 87^{\circ} 43^{\prime}, 470 \mathrm{~m}$ alt, 17.VIII.2012, Ignatov \& Ignatova 12-520 (MHA).

Discussion and Differentiation. When the dataset was under preparation, several specimens were added because the sampling of $H$. mollis was insufficient and its diagnostic characters unclear. Plants from samples found in this clade looked somewhat softer and their hyaline hairpoints seemed to be more slender and less papillose. Otherwise they did not differ sufficiently to suspect them to be anything but a rather average $H$. ciliata.
However, the present analysis revealed it as a distinct entity, though with unclear relationship. Subsequent morphological studies found that such distinction has a certain morphological basis as well. Its spores are constantly smaller than in H. ciliata, 20-25(-28) $\mu \mathrm{m}$ vs. (27.5-)30-35(-37.5) $\mu \mathrm{m}$, only slightly overlapping with $H$. ciliata as it is understood here (see below). Spore ornamentation is also different: in H. mollis it is variable, from flexuose-ridged to coarsely papillose, while in $H$. ciliata ornamentation is more shallow (compare Figs. $23 \mathrm{~J}-\mathrm{O}$ and $24 \mathrm{~A}-\mathrm{F}$ ). The leaf margins are more narrowly and shortly recurved in $H$. mollis in com- 
parison to H. ciliata (cf. Fig. $12 \mathrm{~B}-\mathrm{C}$ and Fig. $15 \mathrm{E}-\mathrm{F}$ ). The papillae on the abaxial leaf surface in $H$. ciliata are large and have long, narrow branches and an irregular arrangement, while in $H$. mollis they are more compact (compare Figs. $20 \mathrm{~J}$ and I). The latter results in papillae that do not overlap cell walls, and likely due to this the longitudinal cell rows are more conspicuous in H. mollis (Figs. $10 \mathrm{D}, 11$ E). The longitudinal cell walls are conspicuously sinuose and often porose in $H$. ciliata (Fig. $20 \mathrm{~J}$ ), while in H. mollis the cell walls are often almost straight or weakly sinuose and not porose (Fig. $10 \mathrm{E}-\mathrm{F}, 20 \mathrm{H}$ ).

Differences from Hedwigia nemoralis include longer hair-points, constituting (17-)23-27(-29)\% of leaf length vs. mainly less than $10 \%$, and larger size of leaves, $1.5-$ $2.0 \times 0.85-1.1 \mathrm{~mm}$ vs. $1.25-1.5(-1.8) \times 0.7-0.9 \mathrm{~mm}$. More numerous, longer, persisting cilia in perichaetial leaves of $H$. mollis vs. few, often broken off cilia in $H$. nemoralis are also helpful (cf. Figs. 10 A vs. 6 B-C and Fig. 21 B vs. $21 \mathrm{C}$ ).

Hedwigia mollis and H. emodica occasionally have some habitual resemblance due to rather long hair-points of the former species (cf. Figs. $10 \mathrm{~B}$ and $17 \mathrm{C}$ ); in these cases the quite different papillae pattern is helpful: in $H$. mollis the papillae are rather compact, not obscuring the cell walls and making longitudinal cell rows conspicuous (Fig. $11 \mathrm{E}, 20 \mathrm{H}$ ), while in $\mathrm{H}$. emodica the papillae are dense, irregularly arranged, making cell wall outlines hardly visible (Fig. $20 \mathrm{~K}$ ).

4. Hedwigia ciliata (Hedw.) P. Beauv., Mag. Encycl. 9(5[19]): 304. 1804. Figs. 13-15; 20 I-J; 21 D, H, J; 22 C; 24 A-F.

Type: Switzerland (lectotype G, selected and commented by Hedenäs, 1994).

Description. Plants in loose or compact tufts, green or greyish green above, brownish below, dull. Stems 3-5 $\mathrm{cm}$ long, moderately to strongly branched. Stem leaves spirally arranged, straight or, often, falcate-secund when dry, with straight or following leaf curvature apices, erectspreading to patent when wet, 1.6-2.0×0.9-1.1 mm, width to length ratio $0.43-0.62$, ovate, acuminate, concave, occasionally weakly plicate; margins \pm widely recurved at lower 2/3-3/4; hyaline hair-points $0.25-0.5 \mathrm{~mm}$ long, constituting $15-25 \%$ of leaf length; margins of hairpoints denticulate, abaxial surface with branched and simple papillae and spinulae in lower part, distal portion of hair-point weakly papillose to smooth, apical cell moderately long, truncate, crowned with $2-3$ papillae, finely papillose or smooth; median leaf cells $12-22(-25) \times 11-$ $14 \mu \mathrm{m}$, with moderately thickened, sinuose, non-porose or clearly porose walls, on abaxial surface with $2-3(-4)$ papillae in each cell, papillae irregularly arranged, strongly branched, with long, narrow branches; on adaxial side with 2-3 smaller, moderately branched and occasionally simple papillae in each cell; cells in the middle of leaf base linear, 50-85×9-11 $\mu \mathrm{m}$, porose, orange-brown, low- ermost cells smooth, then gradually becoming papillose upwards, with several simple papillae per cell, rather abruptly transiting into median leaf cells; basal marginal cells short rectangular, quadrate and transversely rectangular, occasionally with pores on transverse walls. Perichaetial leaves oblong, 2.5-3.2×0.5-1.0 mm, hyaline hair-points $0.5-0.7 \mathrm{~mm}$, cilia numerous, conspicuous in perichaetia. Capsule obovoid or turbinate, $1,1-1.2 \times 1.0$ $1.1 \mathrm{~mm}$. Operculum low conical, with low central mammilla. Exothecial cells in the middle of urn shortly rectangular or irregularly polygonal, at urn mouth in several rows smaller and darker colored. Spores (27.5-)30-35 $(-37.5) \mu \mathrm{m}$, on distal side with low worm-like papillae. Calyptra hairy in lower part.

Distribution and ecology. Hedwigia ciliata is rather frequent in NW European Russia (southern Murmansk Province, Karelia, Leningrad and Pskov Provinces); it was also collected in Tver, Moscow and Orel Provinces in Central European Russia. This species grows mainly on granite cliffs and boulders in forests and in open places, often forming large covers upon rock surfaces.

Selected specimens examined: EUROPEAN RUSSIA: Murmansk Province: Tersky District, Kandalaksha Bay of the White Sea, Porjya Bay, Gorely Island, $66.77305^{\circ} \mathrm{N}, 33.76877^{\circ} \mathrm{E}$, 35 m alt., 27.X.2011, Kozhin M-M-0847 (MW). Republic of Karelia: Petrovsky District, Konchesero Settlement, 26.VII.1954, Katenin s.n., Hepaticae et Musci URSS Exsiccati Decas II (1957), \#14 (MHA). Leningrad Province: Volosovsky District, Shugovitsy Village, 14.V.1985, Ignatov s.n. (MHA); Lomonosovsky District, Cheremykino Settlement, 14.V.1985, Ignatov s.n. (MHA). Pskov Province: Pushkinskie Gory, $57^{\circ} 03^{\prime} \mathrm{N}, 28^{\circ} 57^{\prime} \mathrm{E}, 15$.VIII.2005, Afonina $\Pi 1705$ (LE, MHA); Pskov District, Murovitsy Village, $57^{\circ} 52^{\prime} 14^{\prime \prime} \mathrm{N}, 28^{\circ} 09^{\prime} 25^{\prime \prime} \mathrm{N}$, Zolotov P271 (MHA). Tver Province, Toropetz District, Khvorostjevo Village, 18.VII.1999, Notov s.n. (MW). Moscow, Leninskie Gory, Botanical Garden of Moscow State University, 28.III.2014, Kozhin \& Fedosov Msk-0007 (MW). Orel Province, Livny District, Navesnoe Village, 'Kuzilinka', 28.VI.1999, Zolotov s.n. (MHA). BELARUS: Minsk, Boulder Museum, 6.X.2006, Seregin \& Seregina M-1620 (MW).

Discussion and Differentiation. The analysis of the H. ciliata complex with special attention to the West European material was conducted by Buchbender et al. (2014). Their final analysis found $H$. ciliata s. str. in a clade sister to a $H$. stellata-clade, and their common clade had a sister clade of another species, H. striata.

Three specimens from Sweden and Germany were called, by Buchbender et al. (2014), H. ciliata var. leucophaea. They appeared to be problematic, as they grouped with $H$. ciliata in the ITS tree, whereas in the tree based on chloroplastic and mithochondrial data they formed a clade with $H$. stellata. Therefore they were excluded from the final analysis, and it was concluded that H. ciliata var. leucophaea cannot be maintained with its current morphological circumscription.

However, in our analysis most specimens from GenBank were included (problematic specimens discussed by Buchbender et al., 2014 were called H. ciliata s.1.). 

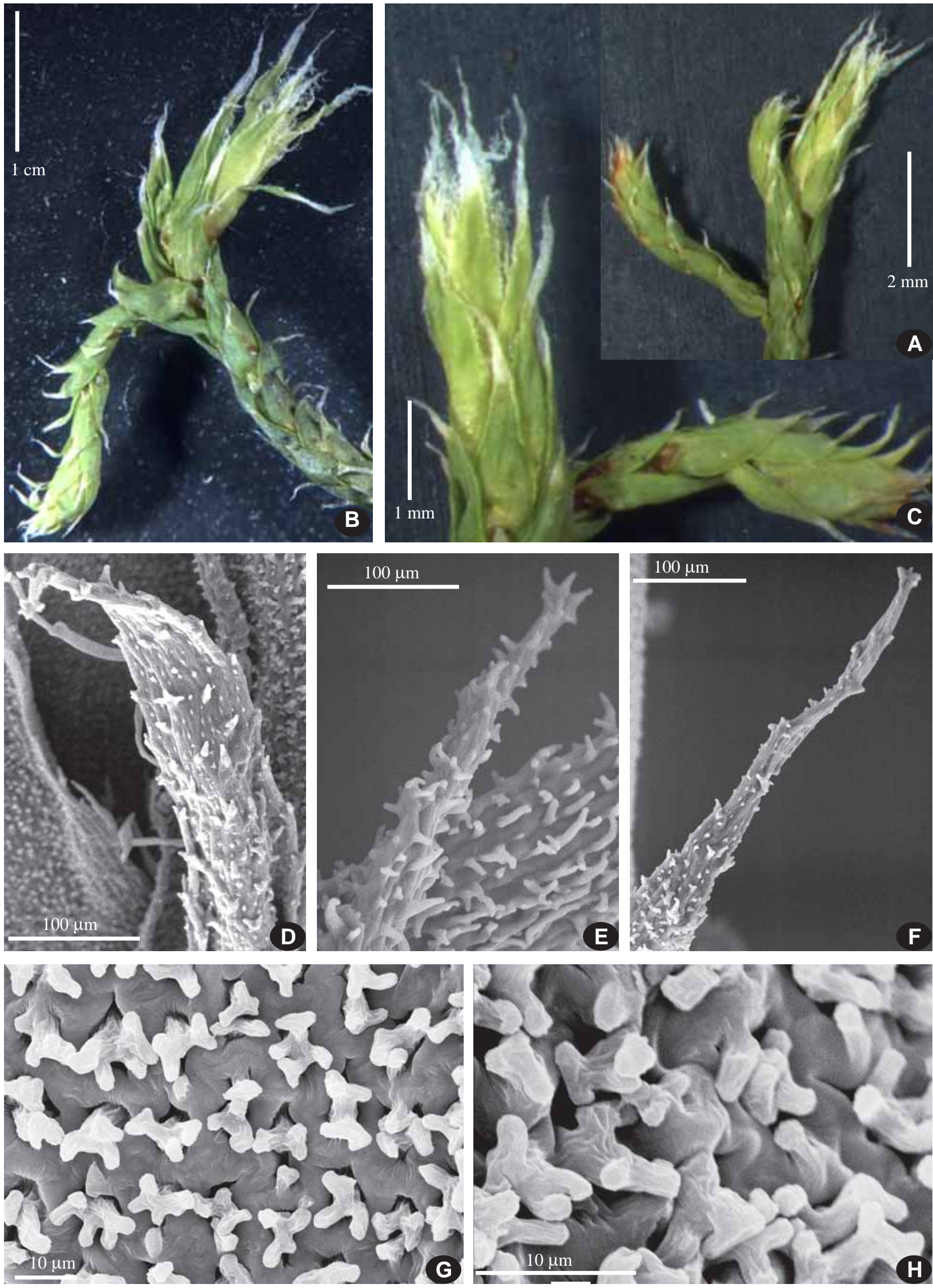

Fig. 13. A-D, F-H: Hedwigia ciliata (A-D, G-H - from: Pskov Province, Afonina 1705, MHA; F - from: Leningrad Province, 14.V.1985, Ignatov s.n., MHA). A-C: habit (SM); D-H (SEM). D, F: apical parts of leaves; G-H: papillae in mid-leaf on abaxial leaf surface. E: Hedwigia sp. (from: Khabarovsk Territory, Ignatov \& Ignatova 13-1128, MHA): leaf apical part (SEM). 

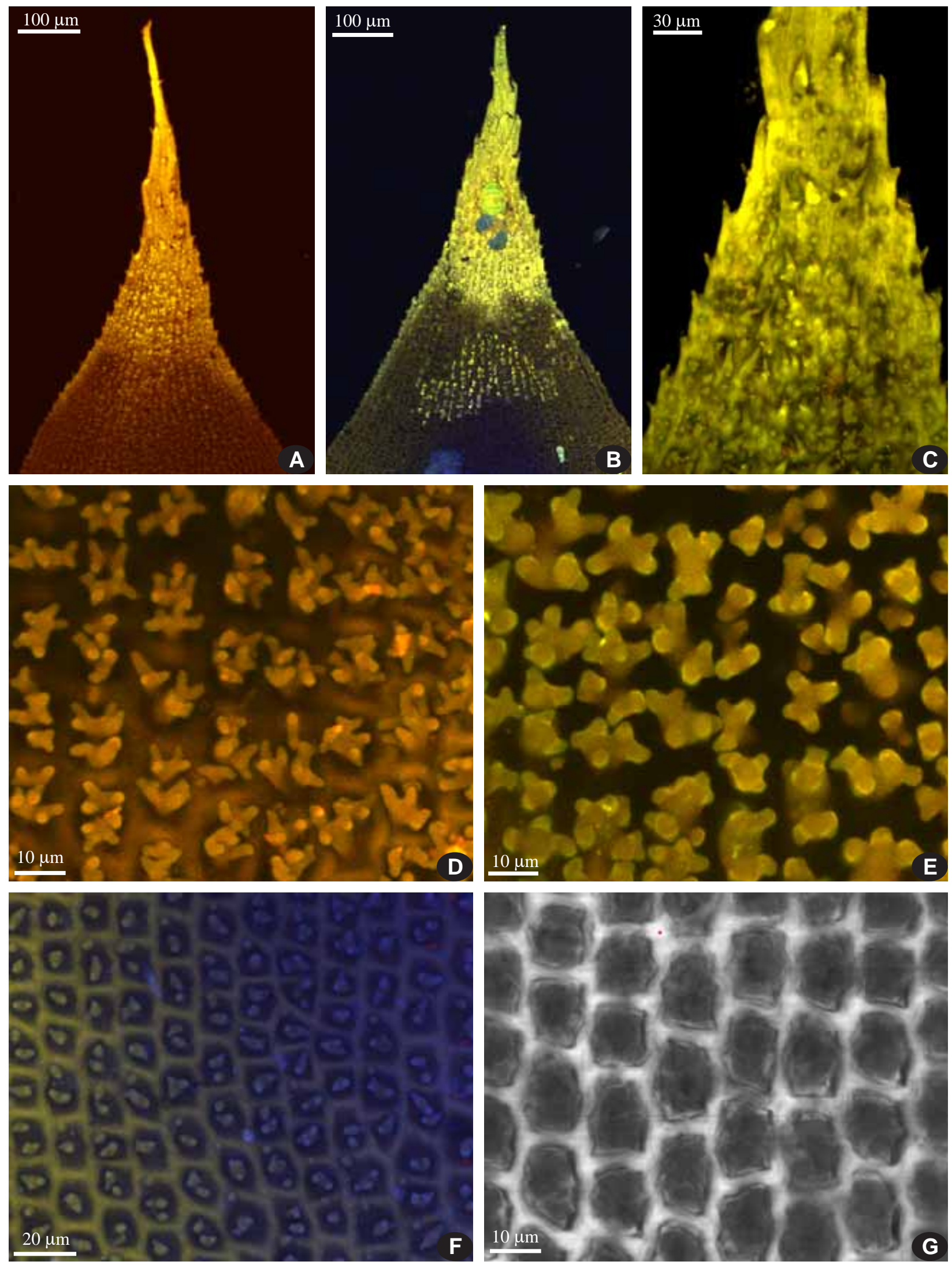

Fig. 14. Hedwigia ciliata (A-D, F-G - from: Pskov Province, Afonina 1705, MHA; E - from: Belarus, Seregin \& Seregina M1620, MW). A-G (LCSM). A-B: apical parts of leaves; C: subapical part of leaf, abaxial view; D-E: papillae in mid-leaf on abaxial side; F: papillae in mid-leaf on adaxial side; G: lamina areolation in mid-leaf. 


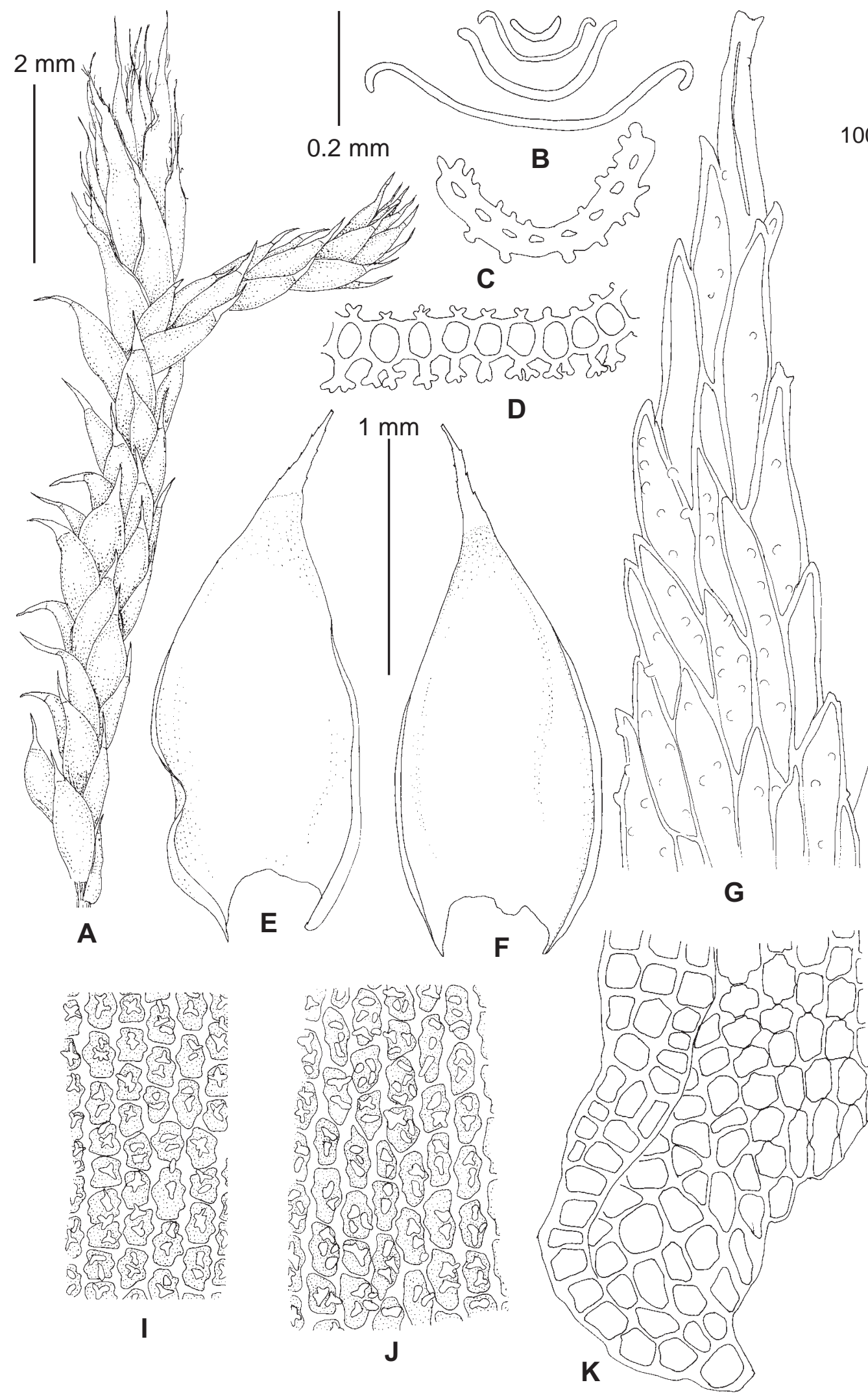

Fig. 15. Hedwigia ciliata (from: Russia, Pskov Province, Afonina P1705, MHA). A: habit, dry; B, D: leaf transverse sections; C: transverse section of hair-point; E-F: stem leaves; G-H: leaf apical parts; I: median leaf cells from abaxial side; J: median leaf cells from adaxial side; K: basal marginal cells; L: cells in the middle of leaf base. Scale bars: $2 \mathrm{~mm}$ for A; $1 \mathrm{~mm}$ for E-F, $0.2 \mathrm{~mm}$ for B; $100 \mu \mathrm{m}$ for $\mathrm{C}-\mathrm{D}, \mathrm{G}-\mathrm{L}$. 

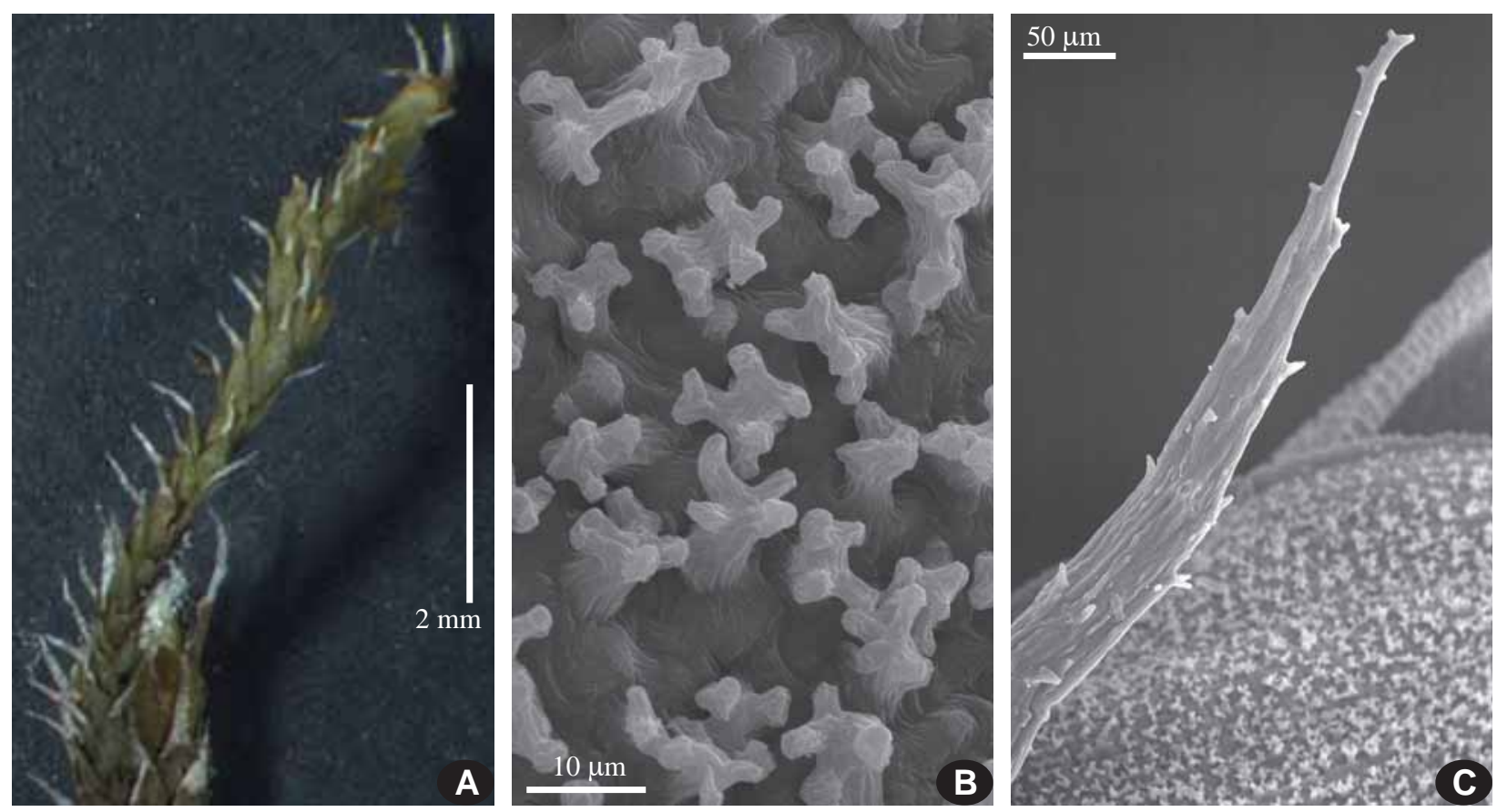

Fig. 16. Hedwigia cf. stellata (from: Norway, Bergen, Ignatov \& Ignatova 06-5134, MHA). A: habit, dry (SM); B-C (SEM). B: papillae in mid-leaf on abaxial side; C: leaf apical part.

All specimens of $H$. ciliata were resolved in the maximally supported clade. Specimens of $H$. ciliata s. str. from Germany and Sweden and several specimens from European Russia (Leningrad, Murmansk and Orel Provinces), Belarus and Bulgaria formed a polytomy, while another group of specimens formed a nested clade within it. This clade includes specimens from Pskov, Tver and Moscow Provinces (called H. ciliata s.1.) plus three Swedish specimens which were exluded from analysis by Buchbender et al. (2014) and our specimen from Norway identified as $H$. stellata; three specimens of $H$. stellata from GenBank appeared as nested within this clade. This subdivision is apparently caused by the difference in nad5 sequences between these groups. Hedwigia ciliata s.str. has a deletion of $53 \mathrm{bp}$ common with $H$. mollis, H. nemoralis and Hedwigia sp. from the Russian Far East, while $H$. ciliata s.l. lacks this deletion, like the rest of the studied species of Hedwigia. Our specimens of H. ciliata s.l. represent the most common phenotype in the northern part of European Russia, totally agreeing with the morphological circumscription of this species; it does not differ in morphology from studied specimens of $H$. ciliata s.str. At the same time, the Norwegian specimen from Bergen has ca. $5 \%$ of cells with two papillae per cells, but otherwise fits H. stellata (Figs. 16, $20 \mathrm{M}-\mathrm{N}$ ) in gametophytic charactes. Being aware of a possible contamination, we resequenced Norwegian specimen from re-extracted DNA, but all three sequences appeared to be identical with the other three obtained from the first extraction.

For morphological characters of $H$. ciliata Buchbender et al. (2014) referred to the description of this species provided by Hedenäs (1994), and we generally also fol- low it. Specimens from Russia, grouping both with $H$. ciliata s. str. and $H$. ciliata s.1., are characterized by (1) leaf apices straight or following leaf curvature in dry state; (2) leaf margins recurved at proximal $2 / 3-3 / 4$ of leaf length; (3) hyaline hair-points moderately long, denticulate at margins, on abaxial side covered by branched and low and high simple papillae in lower part and mostly by low simple papillae in distal portion; (4) cells in midleaf with sinuose and occasionally also porose longitudinal walls (Fig. $20 \mathrm{~J}$ ); (5) papillae in mid-leaf on abaxial side 2-3 per cell, large, branched, with long, narrow branches covering cell walls and more or less obscuring their outlines (Figs. 13 G-H; 14 D-E; 20 I); (6) papillae on adaxial side of leaf less branched and simple, sparse (Fig. 14 F); (7) spores (27.5-)30-35(-37.5) $\mu \mathrm{m}$ in diameter, with low worm-like ornamentation (in SEM least distinct as compared with $H$. nemoralis, H. mollis and H. emodica; see Fig. 24 A-F).

As H. stellata is absent in Russia, we can just confirm the rather complex situation and possible hybridization between $H$. stellata and $H$. ciliata in the northern part of the Europe. However, as $H$. ciliata s.l. and $H$. ciliata s.str. both have large spores and distribution restricted in Russia only to the European part, and especially its North-West, we accept it as a single taxon. The Norwegian ' $H$. stellata' (which is molecularly identical with $H$. ciliata s.1.) obviously requires further study.

We failed to confirm by sequence data any $H$. ciliata from the Caucasus and Asian Russia, despite of a number of attempts to select proper samples. This might be explained by a still insufficient sampling, although even if present there, it must be quite uncommon in the Cau- 
casus and in the area east of Ural Mountains. In the Caucasus three species of Hedwigia were revealed, including H. nemoralis in the Black Sea coastal area, H. mollis in an altitudinal range from forest to the alpine zone, and $H$. emodica ( $=H$. ciliata var. leucophaea) in dryer sites. The latter species is also most common representative of the genus in Asian Russia (see discussion below it).

Four specimens from the Russian Far East (Primorsky and Khabarovsk Territories and Amurskaya Province) were tested for the relationship to H. ciliata. They share with the latter species such morphological characters as secund leaves, moderately long hair-points and papillae pattern, however differ in smaller spore size, less recurved leaf margins (likewise $H$. mollis), and dense, long spinulae on the hair-point surface and at its margins (a unique character, see Fig. $13 \mathrm{E}$ ). In the molecular-phylogenetic tree they were found in a weakly supported clade in the polytomy close to $H$. mollis. It has much in common with the latter species in papillae shape, size and arrangement; their relationship and morphological distinctions need further study.

The identification of $H$. ciliata does not provide difficulties in case of large specimens with well-developed capsules and mature spores, primarily due to its large spores, which is a character differentiating $H$. ciliata from all other species described in the present paper. Additional morphological distinctions are discussed under them as well.

In a view of putative hybridization events between $H$. ciliata and $H$. stellata, we are far from the idea that all other taxa described here are hundred-percent clearly delimited and conflicts between morphology and molecular markers will never be discovered. Moreover, some cryptic species obviously exist, especially in $H$. emodica group, as it was already pointed by Buchbender et al. (2014).

5. Hedwigia emodica Hampe ex Müll. Hal., Flora 61: 82. 1878. - Hedwigia ciliata var. leucophaea Bruch, Schimp. \& W. Gümbel, Bryol. Eur. 3: 153. 273b. 1846. Figs. 17-19; 20 K-L; 21 E; 22 F; 24 G-O.

Syntypes: Himalaya. Ind. Or. in herb. Hampe in BM.

Description. Plants in dense tufts, greyish green or brownish green above, whitish due to conspicuous hairpoints, brown below, dull. Stems 3-5 cm long, usually strongly branched. Stem leaves spirally arranged, straight when dry, erect-spreading to patent when wet, 1.5-1.9× $0.7-0.8 \mathrm{~mm}$, width to length ratio $0.33-0.48(-0.54)$, narrowly ovate, gradually tapering to the apex, concave, not plicate; margins narrowly recurved at lower $1 / 5-1 / 4(-1 / 3)$ or plane; hyaline hair-points $0.5-1.0 \mathrm{~mm}$ long, constituting $30-53 \%$ of leaf length; margins of hair-points sharply denticulate, abaxial surface papillose throughout, with branched and simple papillae and spinulae in lower part, with simple papillae and spinulae in distal portion, apical cell moderately long, pointed, rarely truncate, finely papillose; median leaf cells $12-16(-23) \times 9-12 \mu \mathrm{m}$, with thick, moderately sinuose, non-porose walls, on abaxial surface with $2-3(-4)$ papillae in each cells, papillae irregularly arranged, strongly branched, with thick, rounded at tips branches, making cell wall outlines hardly visible; on adaxial side with 2-3 smaller, otherwise similar papillae in each cell; cells in the middle of leaf base linear, 50-65×10 $\mu \mathrm{m}$, porose, orange-brown, papillose almost to the leaf base except lowermost 1-2 cell rows, with several simple papillae per cell, gradually transiting into median leaf cells; basal marginal cells short rectangular, quadrate and transversely rectangular, with thick and porose transverse walls. Perichaetial leaves oblong, 2.0-2.9× $0.5-0.6 \mathrm{~mm}$, hyaline hair-points $1.0-1.2 \mathrm{~mm}$, cilia numerous, conspicuous in perichaetia. Capsule cup-like, ca. $0.9-1.0 \times 0.9-1.1 \mathrm{~mm}$. Opercula low conical, with low central mammilla. Exothecial cells in the middle of urn short rectangular or irregularly polygonal, at urn mouth in several rows smaller and darker colored. Spores 20 $25(-27.5) \mu \mathrm{m}$, on distal side with thick worm-like papillae. Calyptra hairy in lower part.

Distribution and ecology. Hedwigia emodica is the most widespread and frequent taxon of the genus in Russia, especially in its Asian part. It is rather common in the Caucasus and southern Siberia, from Altai Mts. to Transbaikalia; it was also sporadically collected in Murmansk Province, Northern Urals, southern Taimyr, central and eastern part of Yakutia, Amurskaya Province, Khabarovsk and Primorsky Territories, and Kamchatka. It grows in a wide altitudinal range, from forest to the alpine belt in the mountains, occasionally in mesic habitats, but more often in dry conditions, on dry south-faced cliffs and rock outcrops on southern slopes, on dry rocks in open places, etc.

Selected specimens examined: EUROPEAN RUSSIA: Ka-

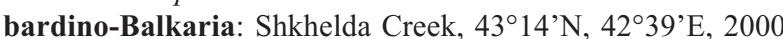
$\mathrm{m}$ alt., 29.VII.2004, Ignatov, Ignatova \& Kharzinov s.n. (MHA); Cherk Bezengijsky River valley $1 \mathrm{~km}$ upstream Dumala Creek mouth, $43^{\circ} 10^{\prime} \mathrm{N}$, 43ำ $14^{\prime} \mathrm{E}, 1650 \mathrm{~m}$ alt., 1.VIII.2004, Ignatov, Ignatova \& Kharzinov s.n. (MHA). Alania/North Ossetia, North Ossetian Nature Reserve, upper course of Tsei River, 21.VII.1976, L.I. Abramova s.n. (MW). Karachaevo-Cherkessia: Teberda Nature Reserve, Ullu-Murudzhu Creek valley, 1700 $\mathrm{m}$ alt., 7.VIII.1986, Ignatova s.n. (MHA); Dagestan, Rutulsky District, between Gelmetz and Tsahurb Villages, $41.45567^{\circ} \mathrm{N}$, $47.7695^{\circ} \mathrm{E}, 1650 \mathrm{~m}$ alt., 22.V.2010, Fedosov 10-2-244 (MW). Perm Territory, Vishersky Nature Reserve, Vishersky Kamen

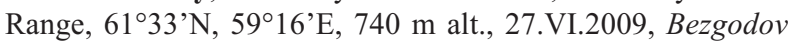
79 (MHA). ASIAN RUSSIA: Altai Republic: Ulagan District, Chulyshman River valley, Yazula, 51 ${ }^{\circ} 38^{\prime} \mathrm{N}, 88^{\circ} 57^{\prime} \mathrm{E}, 1600 \mathrm{~m}$ alt., 25.VI.1989, Ignatov 0/1095 (MHA); Kosh-Agach District, Taldura Creek, $49^{\circ} 57^{\prime} \mathrm{N}, 87^{\circ} 50^{\prime} \mathrm{E}, 2250 \mathrm{~m}$ alt., 11.VIII.2012, Ignatov \& Ignatova 12-374 (MHA); Ongudai District, Malyj Yaloman, $50^{\circ} 28^{\prime} \mathrm{N}, 86^{\circ} 33^{\prime} \mathrm{E}, 1100 \mathrm{~m}$ alt., 30.VII.1991, Ignatov \& Ignatova 25/4 (MHA). Krasnoyarsk Territory: State Biosphere Nature Reserve Taimyrsky, Kotuj River, $71.1272^{\circ} \mathrm{N}$, $102.548^{\circ} \mathrm{E}, 5 . \mathrm{VII} .2005$, Pospelov 05-401 (MW); Baikit District, Central-Siberian Nature Reserve, Podkamennaya Tungus-

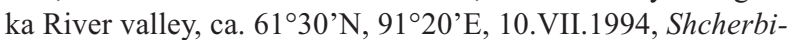
na 275 (MW). Republic of Sakha/Yakutia: Tomponsky District, between Sukhaya and Kyurbellyakh Creeks, Southern 

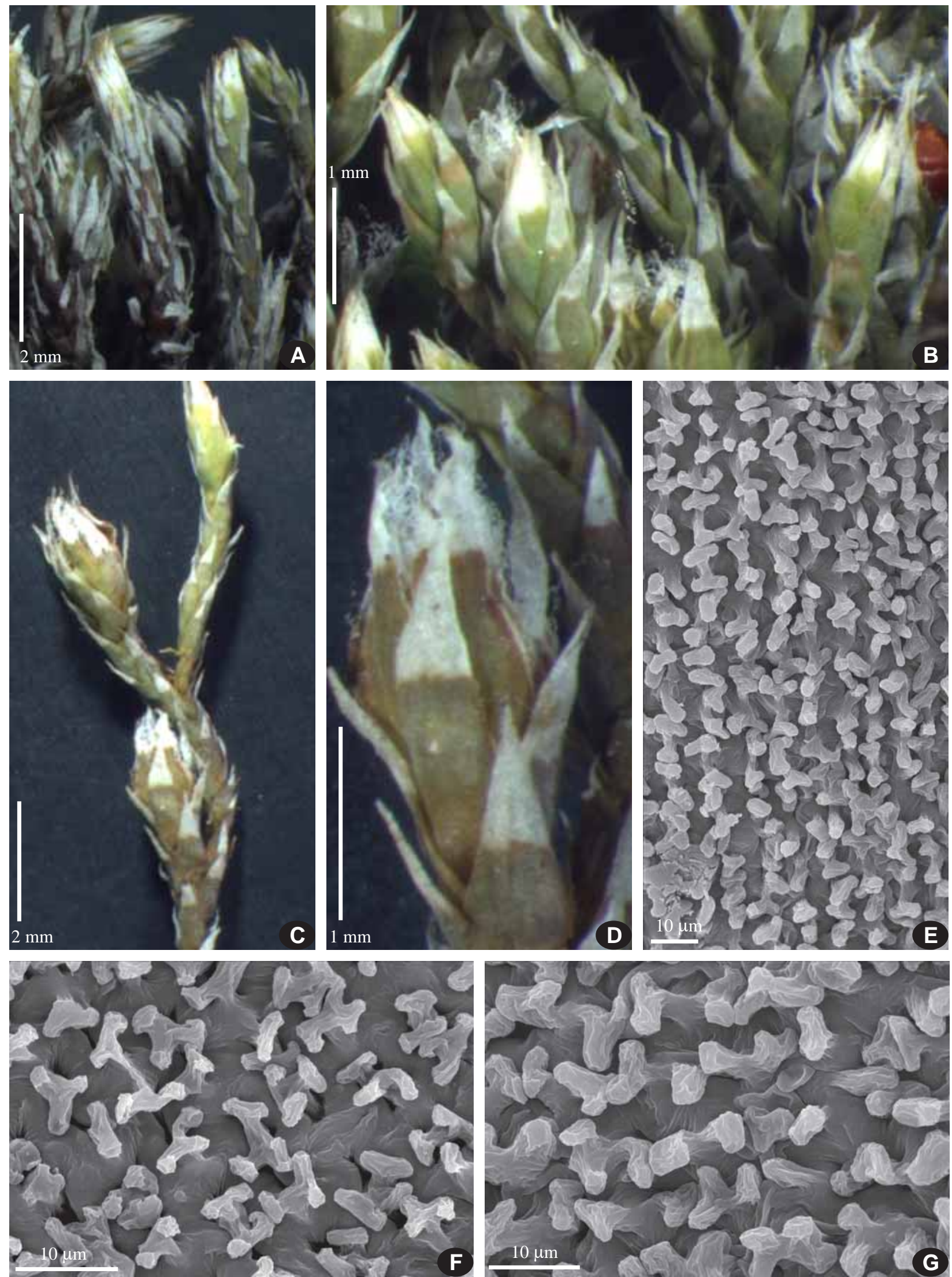

Fig. 17. Hedwigia emodica (A - from: Yakutia, Ignatov \& Ignatova 15-1496, MHA; B - from: Perm Territory, Bezgodov 79, MHA; C-D - from: Kabardino-Balkaria, 1.VIII.2004, Ignatov et al. s.n., MHA; E, G - from: Zabaikalsky Territory, Afonina 3411, LE, MHA; F - from: Kamchatka, Czernyadjeva 105, LE, MHA). A-D: habit (SM); E-G: papillae in mid-leaf on abaxial leaf surface (SEM). 

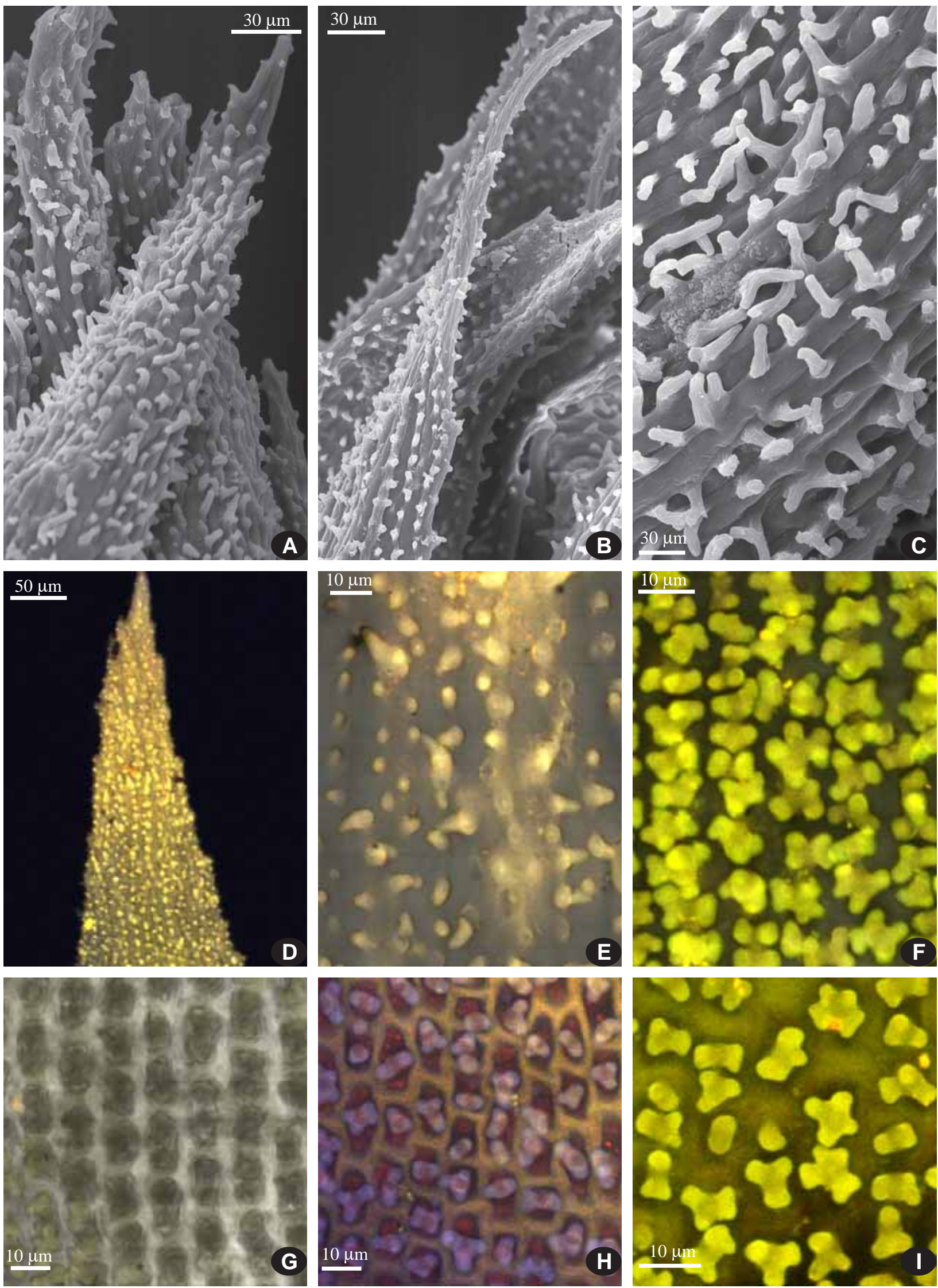

Fig. 18. Hedwigia emodica (A-E, H: Perm Territory, Bezgodov 79, MHA; F, G, I: Kabardino-Balkaria, 1.VIII.2004, Ignatov et al. s.n., MHA). A-C (SEM). A-B: leaf apical parts; C: leaf subapical part, abaxial view. D-I (LCSM). D: leaf apical part; E: abaxial surface of lower part of hair-point; F: papillae in mid-leaf on abaxial side; G: lamina areolation in mid-leaf; H-I: papillae in midleaf on adaxial surface. 


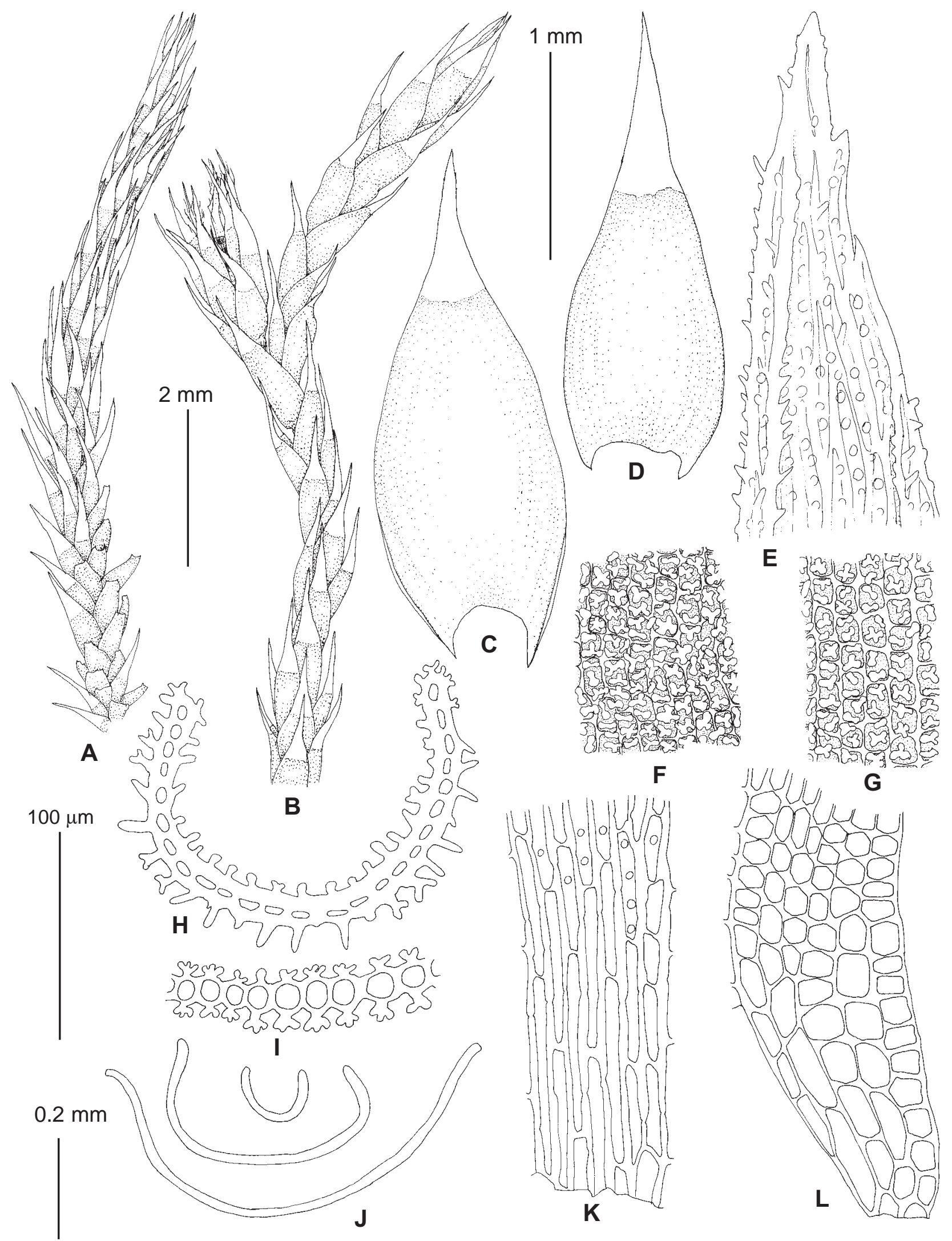

Fig. 19. Hedwigia emodica (A, D - from: Yakutia, Ignatov \& Ignatova 15-1496, MHA; B-C, E-L - from: Kabardino-Balkaria, 29.VII.2004, Ignatov et al. s.n., MHA). A-B: habit, dry; C-D: stem leaves; E: leaf apical part; F: median leaf cells from abaxial side; G: median leaf cells from adaxial side; H: transverse section of hair-point; I-J: leaf transverse sections; K: cells in the middle of leaf base; L: basal marginal cells. Scale bars: $2 \mathrm{~mm}$ for A-B; $1 \mathrm{~mm}$ for C-D, $0.2 \mathrm{~mm}$ for J; $100 \mu \mathrm{m}$ for E-I, K-L. 
slope of Baranja Mt., 6306'59'N, 139 00'10'E, $1050 \mathrm{~m}$ alt., 22.VII.2015, Ignatov \& Ignatova 15-163 (MHA); Oimyakon District, $60 \mathrm{~km}$ E of Ust-Nera Settlement, Topol Creek mouth, $64^{\circ} 27^{\prime} 20^{\prime} \mathrm{N}, 144^{\circ} 21^{\prime} 30^{\prime} \mathrm{E}, 600 \mathrm{~m}$ alt., 5.VIII.2015, Ignatov \& Ignatova 15-1471 (MHA). Amurskaya Province: Zeya Nature Reserve, Tukuringra Range, Gilyuj River bank, $54.2668^{\circ} \mathrm{N}$, $126.8531^{\circ} \mathrm{E}, 344 \mathrm{~m}$ alt., 26.VII.2012, Dudov Br 12009 (MW); Selemdzhinsky District, Ust-Norskaya Sopka, 52 ${ }^{\circ} 23^{\prime} 30^{\prime \prime} \mathrm{N}$, $129^{\circ} 56^{\prime}$ E, 220 m alt., 18.VI.2011, Bezgodov 313 (MHA). Khabarovsk Territory: Verkhnebureinsky District, Bureinsky State Reserve, Bureya River near Umalta-Makit River mouth, $51^{\circ} 39^{\prime} \mathrm{N}, 134^{\circ} 16^{\prime} \mathrm{E}, 550 \mathrm{~m}$ alt., 28.VIII.1997, Ignatov 97-2020 (MHA); Sovgavan District, Botchinsky Nature Reserve, Dlinnyj Creek, $48^{\circ} 17^{\prime} \mathrm{N}, 139^{\circ} 35^{\prime} \mathrm{E}, 315 \mathrm{~m}$ alt., 13.VIII.2013, Ignatov \& Ignatova 13-404 (MHA). Zabaikalsky Territory, Kyra District, Sokhondinsky Nature Reserve, Agitsa River, $49^{\circ} 38^{\prime} \mathrm{N}$, $111^{\circ} 27^{\prime} \mathrm{E}, 1170 \mathrm{~m}$ alt., 19.VII.2010, Czernyadjeva 29-10 (LE). Kamchatka Peninsula, Sredinnyj Range, Esso, 55 $55^{\circ}$ 'N, $158^{\circ} 42^{\prime} \mathrm{E}, 700 \mathrm{~m}$ alt., 21.VIII.2003, Czernyadjeva 105 (LE). Primorsky Territory: Ussurijsky Nature reserve, Koryavaya Pad', Zmeinaya Mt., 43³8'24.9”N, 132³3'40.8”E, $191 \mathrm{~m}$ alt., 15.X.2008, Ignatov 08-277 (MHA); Partizansky District,

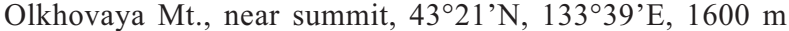
alt., 3.IX.2006, Ignatov, Ignatova \& Cherdantseva 06-2621 (MHA).

Discussion and Differentiation. Before the present molecular analysis was done, we were quite skeptical on the possibility to separate $H$. ciliata var. ciliata from $H$. ciliata var. leucophaea (H. emodica). Now it turns out that the important reason for this was simply the quite restricted range of $H$. ciliata in Russia. Hedenäs (1994) suggested spore size as one of the distinctive characters, but in Asian Russia where we mainly conducted our studies, there is no large-spored Hedwigia at all, while smallspored plants look very heterogeneous: as $H$. emodica and $H$. mollis both are common in South Siberia, and they have similar spore size.

The molecular phylogenetic study left the majority of the Asian plants in a polytomy or poorly supported clade. Nevertheless they are morphologically rather similar; all other taxa were found in highly supported clades, therefore these Asian plants have to be supplied with a separate name. Having only a remote affinity to $H$. ciliata, this taxon cannot be referred to $H$. ciliata var. leucophaea. The oldest existing name for this taxon at the species rank, according to Hedenäs (1994) is H. emodica, thus with only a little hesitation we suggest to use it for this most common and widespread taxon of Hedwigia in Russia.

In most cases $H$. emodica is readily recognized by straight leaves and long, conspicuous hair-points, pure white, contrasting with greyish-green lower leaf portions, which makes the tufts variegated. Smaller spores, 20-25 $(-27.5) \mu \mathrm{m}$ vs. (27.5-)30-35(-37.5) $\mu \mathrm{m}$ is another useful character for separating it from $H$. ciliata. Among other characters are (1) narrowly recurved leaf margins in $H$. emodica vs. broadly recurved in $H$. ciliata; and (2) papillae on the abaxial leaf surface dense and having thick branches, while they are less dense, irregularly arranged, with narrow branches in $H$. ciliata (compare Figs. 17 E-
G, $18 \mathrm{~F}$ and $20 \mathrm{~K}$ with Figs. $13 \mathrm{G}-\mathrm{H}, 14 \mathrm{D}$ and $20 \mathrm{I}$ ). There is also a peculiar difference in cell wall fluorescence under LSCM, which is almost absent in H. emodica and bright in $H$. ciliata in slides stained with berberin.

The sympatric $H$. czernyadjevae differs in unipapillose laminal cells and a long apical cell. Sometimes it also has an expanded hyaline area in distal portions of the leaves, so in this case study of papillae is essential, if other characters (e.g., long and pointed apical cells, hairy calyptra, rather ovate than conic-obovate capsule) do not help.

Hedwigia nemoralis with short hair-points and weakly ciliate perichaetial leaves is quite unlikely be confused with $H$. emodica. For the difference from $H$. mollis see comments under that species.

\section{COMMENTS ON ADDITIONAL CHARACTERS}

Papillae are very variable in Hedwigia, being different in different parts of leaves. For this reason, their shape and size could be considered only moderately useful, especially in cases of identification of solitary specimens among collections which represent the entire flora. However, if numerous specimens of Hedwigia are revised, the differences in papillosity pattern between species become more obvious. Thus, in addition to general illustrations, we also provide a table of cell photos at the same magnification, taken from the same area of the abaxial leaf surface, in the center between the mid-leaf (without hair-point) and the base of the hair-point (Fig. 20). Below this area papillae are usually smaller, while shortly below the hyaline hair-point and upon its base they are 'too prominent', occasionally elk horn-shaped, but much more variable than somewhat below.

The size of papillae in $H$. ciliata often exceeds 10 $\mu \mathrm{m}$, while in $H$. nemoralis they are $7-9 \mu \mathrm{m}$ wide, and in H. mollis 6-8 $\mu \mathrm{m}$ wide (Fig. 20). Cell lumen outlines and presence or absence of pores in cell walls is also shown in these pictures

Perichaetial leaves (Fig. 21 A-E) are strongly ciliate in $H$. ciliata, $H$. mollis and H. emodica. In H. nemoralis they are weakly ciliate. In $H$. czernyadjevae ciliae are fewer and more robust, somewhat reminding those of European H. striata (Fig. 21 B).

Capsule shape is especially distinct in H. czernyadjevae: it is ovate to obovate, with the broadest part shortly above the middle, whereas other species have obovate to obconic capsules, broadest just below their mouths. In $H$. emodica a limited number of observations revealed a shorter urn (Fig. 22).

Calyptra is a character rarely checked in Hedwigia. It falls off early and often remains among perichaetial leaves, up to a stage when most spores have already been released. As the vaginula is invariably very hairy in Hedwigia, the base of calyptrae (being at epygonium stage immediately connected with vaginula) often has a certain amount of hairs (Fig. $21 \mathrm{G}-\mathrm{H}$ ). A marked contrast to all species is provided by $H$. czernyadjevae that has calyptrae hairy almost throughout (Fig. $21 \mathrm{~F}$ ). 

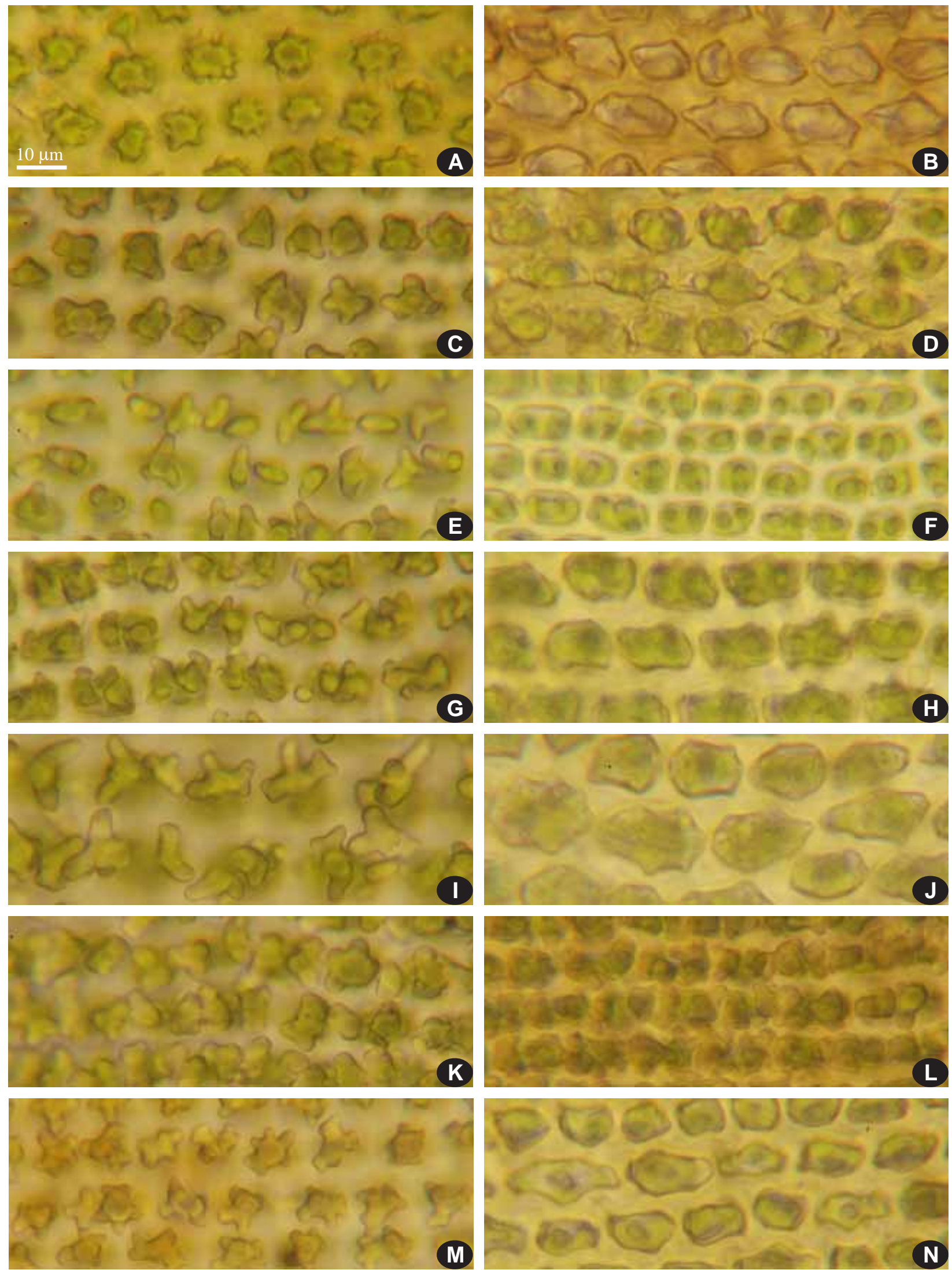

Fig. 20. A-B: Hedwigia detonsa (from: U.S.A., California, 7.VIII.1989, Ignatov s.n., MHA); C-D: H. czernyadjevae (from: Zabaikalsky Territory, Czernyadjeva 37-11, MHA); E-F: H. nemoralis (from: Primorsky Territory, Ignatov 07-324,MHA); G-H: H. mollis (from: Bashkortostan, Zolotov 13-18, MHA); I-J: H. ciliata (from: Pskov Province, Zolotov P271, MHA); K-L: H. emodica (from: KabardinoBalkaria, 29.VII.2004, Ignatov et al. s.n., MHA); M-N: H. cf. stellata (from: Norway, Ignatov \& Ignatova 06-5134, MHA). A, C, E, G, I, K, M: papillae in mid-leaf on abaxial side; B, D, F, H, J, L, N: lamina areolation in mid-leaf. All LM. Scale bar $10 \mu \mathrm{m}$ for all. 

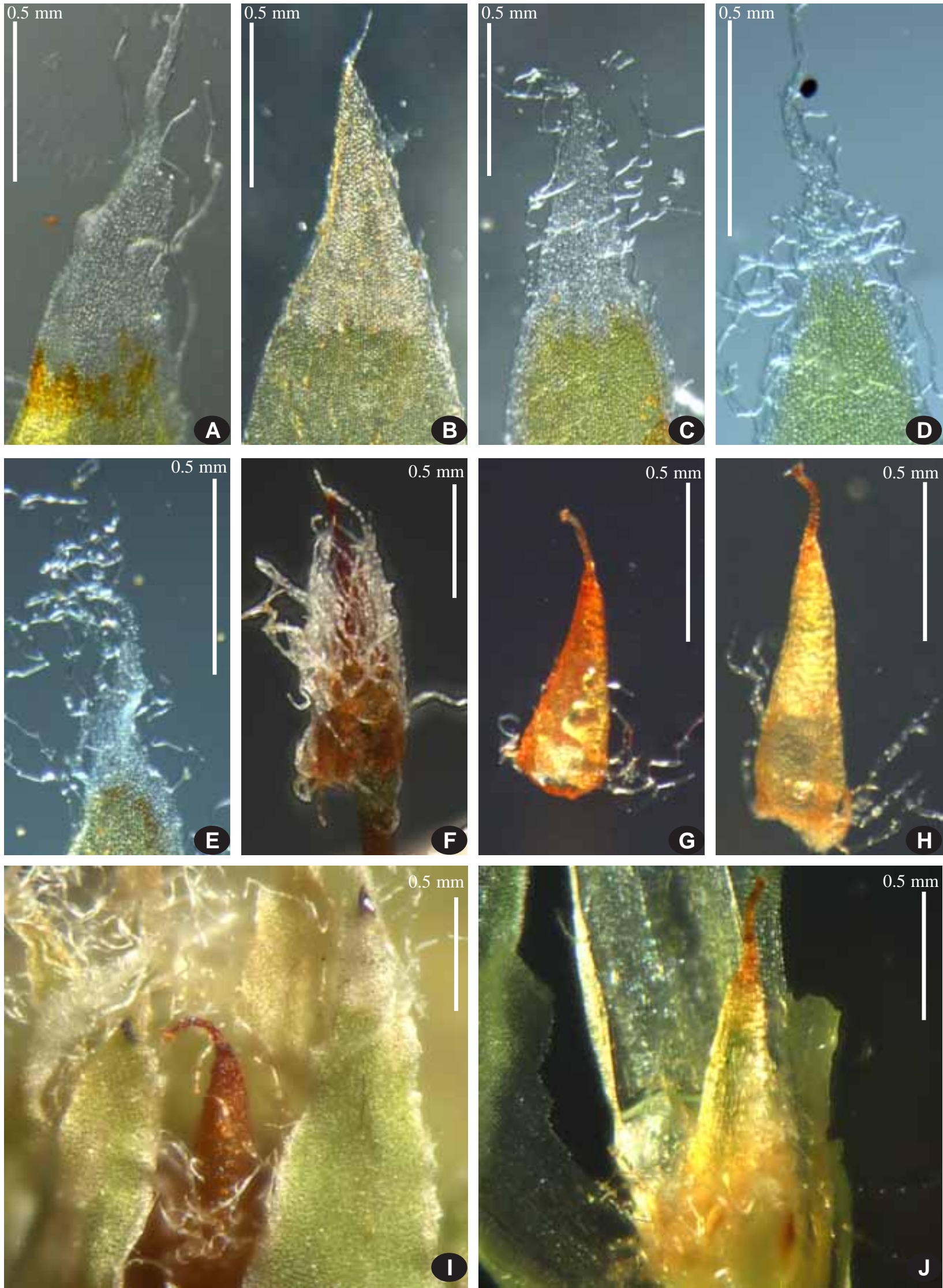

Fig. 21. A, F: H. czernyadjevae (Zabaikalsky Territory, Czernyadjeva 37-11, MHA); B: H. nemoralis (Primorsky Territory, Ignatov 07-324, MHA); C, G, I: H. mollis (Altai, Ignatov \& Ignatova 12-520, MHA); D: H. ciliata (Pskov Province, Afonina P1705, MHA; E: H. emodica (Kabardino-Balkaria, 1.VIII.2004, Ignatov et al., MHA); H, J: H. ciliata (Belarus, Seregin \& Seregina M-1620, MW). A-E: apical parts of perichaetial leaves; F-H: calyptrae; I-J: perichaetia. All SM. 

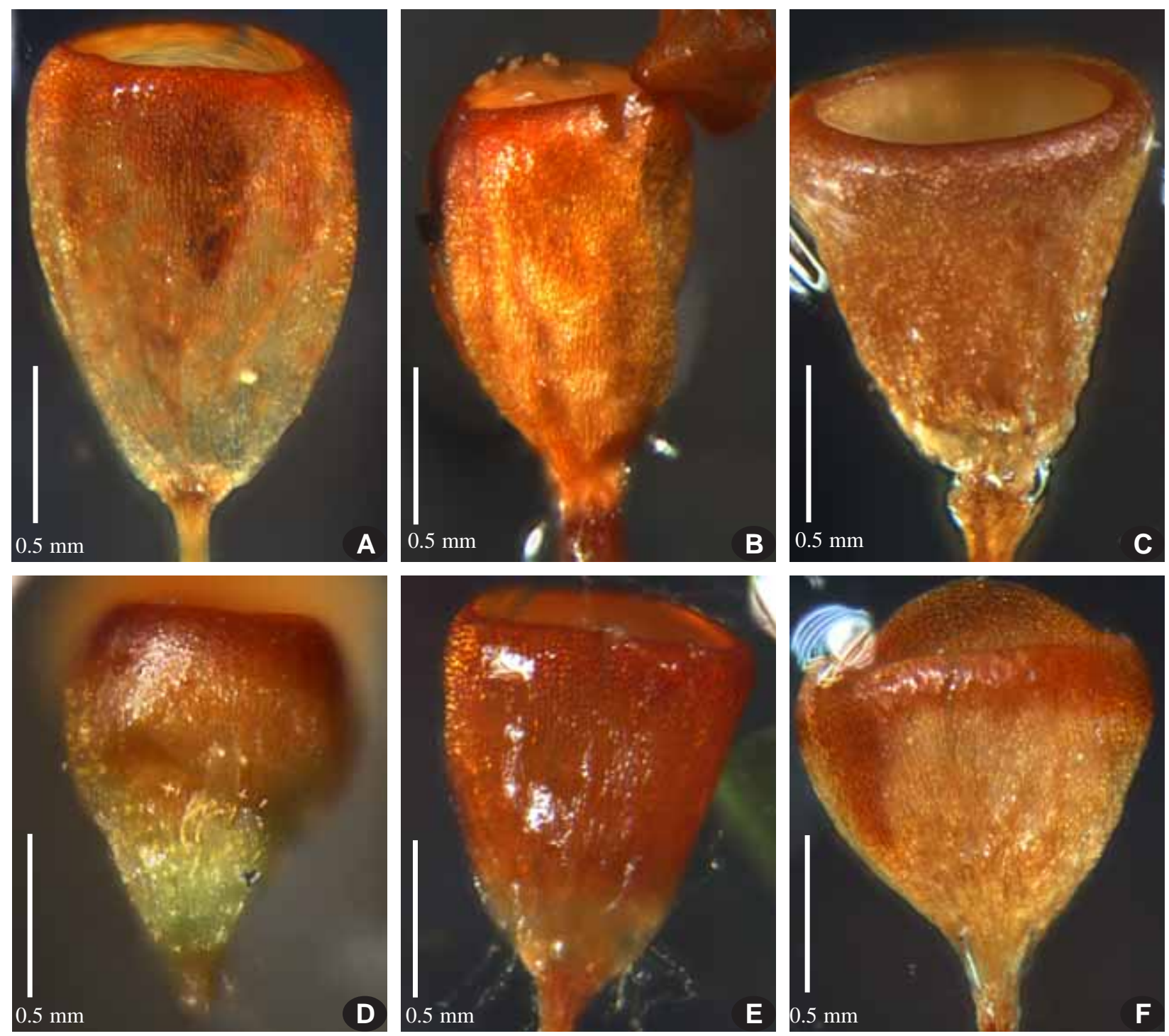

Fig. 22. A-B: H. czernyadjevae (from: Zabaikalsky Territory, Czernyadjeva 37-11, MHA); C: H. ciliata (from: Pskov Province, Afonina P1705, MHA; D: H. nemoralis (from: Krasnodar Territory, Sochi, Ignatov \& Ignatova 12-89, MHA); E: H. mollis (from: Altai, Ignatov \& Ignatova 12-520, MHA); F: H. emodica (from: Kabardino-Balkaria, 1.VIII.2004, Ignatov et al. s.n., MHA). A-F: capsules (SM).

Spore surface sculpture is moderately useful for practical identification; a possibility to observe it considerably depends on the quality of microscope, unless a 100x objective lens is used. However, SEM observations indicate its significance for taxa delimitation.

The overall ornamentation is shown in Figs. 23-24. In most cases, spores of Hedwigia have worm-like ridges on their surface, occasionally with an admixture of round papillae. These ridges may be flattened (in H. ciliata, Fig. $24 \mathrm{~A}-\mathrm{F}$ ) or well-separated, shorter and thicker (in H. emodica, Fig. $24 \mathrm{G}-\mathrm{O}$ ) or confluent, becoming labyrinth-like (in H. nemoralis, Fig. 23 D-I). However, in some specimens spore surface unusual for the species was occasionally observed (compare Fig. $23 \mathrm{~J}$ and $23 \mathrm{~K}-\mathrm{O}$, showing spores of $H$. mollis). It presumably depends on the stage of spore development and environment conditions.
Furthermore, it is difficult to observe minute details of the spore surface even under microscope of good quality.

\section{ACKNOWLEDGEMENTS}

Authors are sincerely grateful to L. Hedenäs for valuable comments on the manuscript and language improvement. The work on SEM was performed partially at User Facilities Center of M.V. Lomonosov Moscow State University under financial support of Ministry of Education and Science of Russian Federation, and partially in Main Botanical Garden under supervising of A.V. Babosha to whom we are sincerely grateful. We also thank the curators of herbaria LE and VBGI who made their collections available to us. The study of Ignatova was supported by RFBR grant \#15-04-06027, of Fedosov by \#1404-01424, and of Kuznetsova and Ignatov by \#15-2902647. 

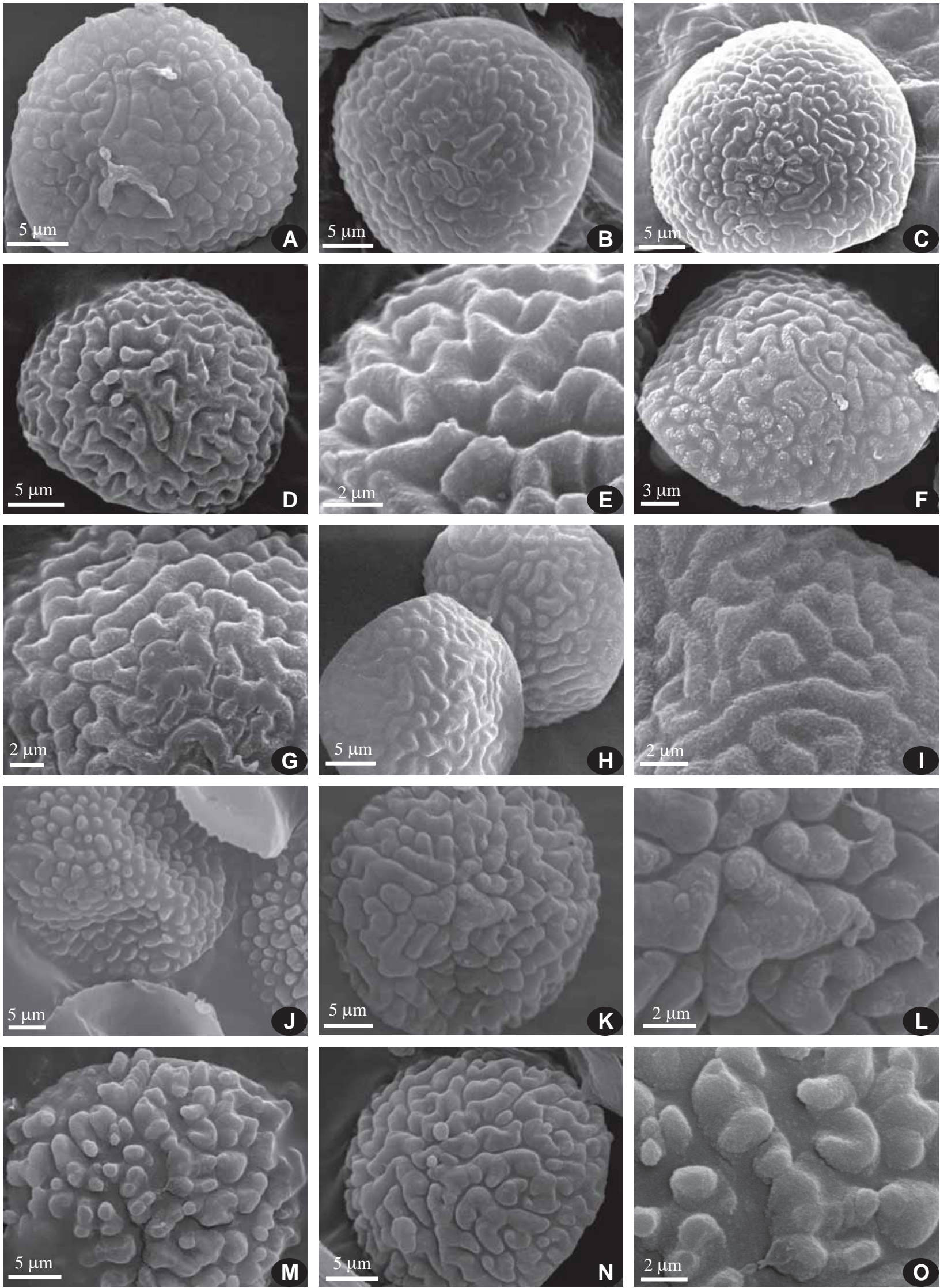

Fig. 23. Spores of Hedwigia (SEM). A-C: H. czernyadjevae (A: Zabaikalsky Territory, Czernyadjeva 37-11, LE; B-C: Khabarovsk Territory, Iwatsuku 60522, MHA); D-I: H. nemoralis (D-E: Zabaikalsky Territory, Afonina 3411, LE; F: Primorsky Territory, Ignatov 07-324, MHA; G: Georgia, Bakalin G-11-60-13, MHA; H-I: U.S.A. 9.II.2008, Tsegmed, MHA); J-O: H. mollis (J: Altai, Ignatov \& Ignatova 12-520, MHA; K-L: Karelia, 13.IV.1997, Bakalin \& Bakalina, MHA; M-O : Altai, Ignatov 0/1094, MHA). 

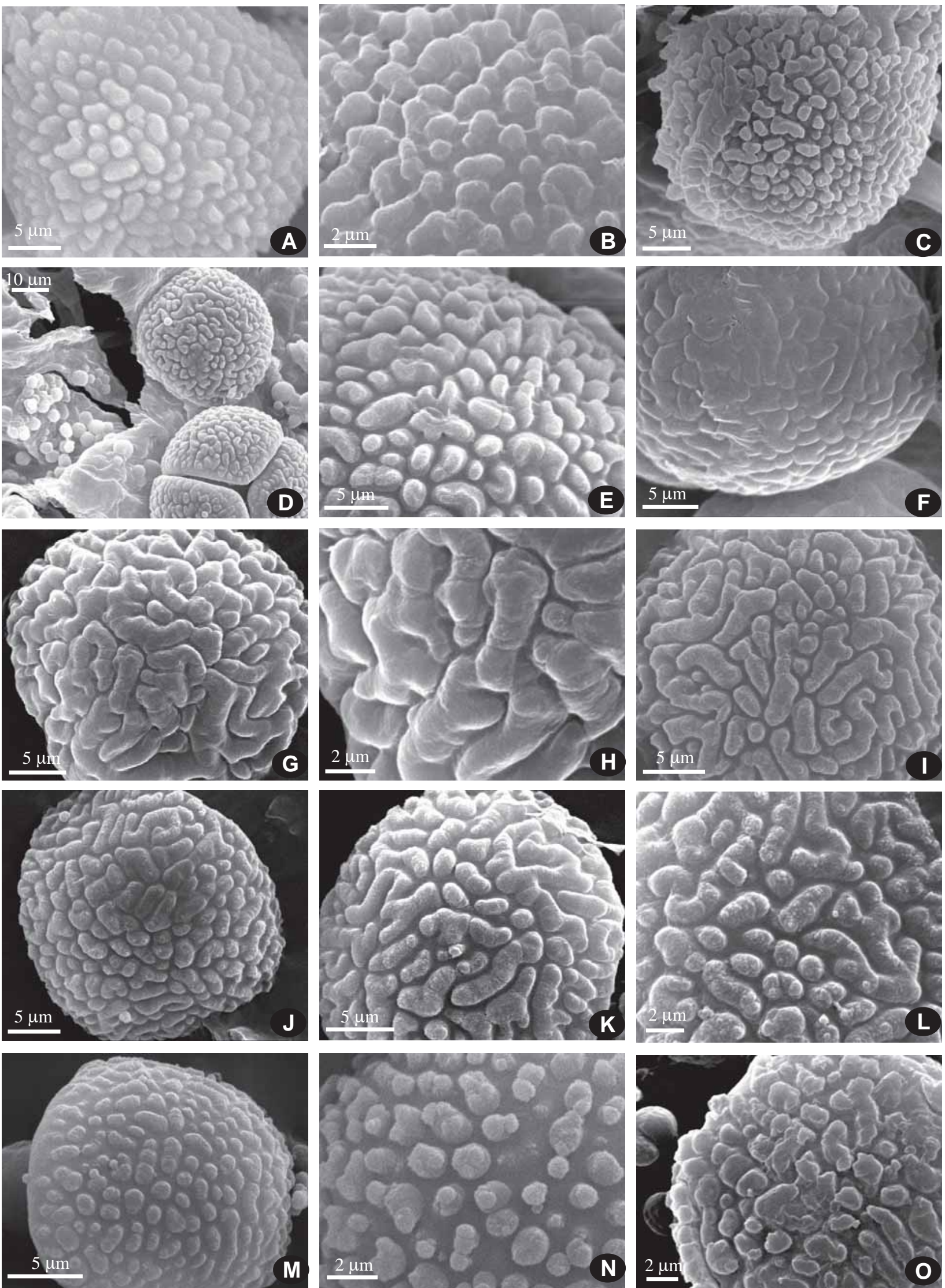

Fig. 24. Spores of Hedwigia (SEM). A-F: H. ciliata (A: Finland, Brotherus, Bryoth. Fenn. \#69, MW; B: Germany, Krieger, Musci eur. exs. \#839, MW; C: Tver Prov., 18.VII.1999, Notov, MW; D-E: Belarus, Seregin \& Seregina M-1620, MW; F: Leningrad Prov., 14.V.1985, Ignatov, MHA). G-O: H. emodica (G-H: Kabardino-Balkaria, 29.VII.2004, Ignatov et al., MHA; I: Taimyr, Fedosov 09-363, MHA; J-L: Kabardino-Balkaria, 1.VIII.2004, Ignatov et al., MHA; M-N: Perm Prov., Bezgodov 79, MHA; O: Primorsky Terr., Ignatov 08-277, MHA). 


\section{LITERATURE CITED}

AFONINA, O.M. \& I.V. CZERNYADJEVA. 2012. New moss records from Zabaikal'sky Territory. 4. - In: Sofronova, E.V. (ed.) New bryophyte records. 1. - Arctoa 21: 294

[AFONINA, O.M., YU.S. MAMONTOV \& I.V. CZERNYADJEVA] АФОНИНА О.М., Ю.С. МАМОНТОВ, И.В. ЧЕРНЯДЬЕВА. 2012. Мхи и печеночники Сохондинского государственного заповедника. - [Mosses and liverworts of Sokhondinsky State Reserve] СПб. [St.-Peterburg]: $200 \mathrm{pp}$.

ANDERSON, L. E., H. A. CRUM \& W. R. BUCK. 1990. List of mosses of North America north of Mexico. - Bryologist 93: 448-499.

BIASUSO, A.B. 2007. The genus Hedwigia (Hedwigiaceae, Bryophyta) in Argentina. - Lindbergia 32: 5-17.

BROTHERUS, V.F. 1925. Musci (Laubmoose) 2. - In: H. G. A. Engler \& K. Prantl (eds.) Nat. Pflanzenfam. (ed. 2). Duncker \& Humblot, Berlin: 1-542.

BUCHBENDER, V., H. HESPANHOL, M. KRUG, C. SÉRGIO, A. SÉNECA, K. MAUL, L. HEDENÄS \& D. QUANDT. 2014. Phylogenetic reconstructions of the Hedwigiaceae reveal cryptic speciation and hybridisation in Hedwigia. - Bryophyte Diversity \& Evolution 36(1): 1-21.

BUCK, W. R. \& D. H. NORRIS. 1996. Hedwigia stellata and H. detonsa (Hedwigiaceae) in North America. - Nova Hedwigia 62: 361-370.

CORLEY, M.F.V., A.C. CRUNDWELL, R. DÜLL, M.O. HILL \& A.J.E. SMITH. 1981. Mosses of Europe and the Azores: an annotated list of species, with synonyms from the recent literature. - Journal of Bryology 11: 609-689

DALTON, N.J., E.M. KUNGU \& D.G. LONG. 2013. A taxonomic revision of Hedwigiaceae Schimp. from the Sino-Himalaya. - Journal of Bryology 35(2): 96-111.

ERZBERGER, P. 1996. Zur Verbreitung von Hedwigia stellata in Europa. - Herzogia 12: 221-238

FEDOSOV, V.E., A.V. FEDOROVA, A.E. FEDOSOV \& M.S. IGNATOV. 2016. Phylogenetic inference and peristome evolution in haplolepideous mosses, focusing on Pseudoditrichaceae and Ditrichaceae s. 1. - Botanical Journal of the Linnean Society 181: 139-155.

FELSENSTEIN, J. 1985. Confidence limits on phylogenies: an approach using the bootstrap. - Evolution 39: 783-791.

GARDINER, A., M. IGNATOV, S. HUTTUNEN \& A. TROITSKY. 2005. On resurrection of the families Pseudoleskeaceae Schimp. and Pylaisi- aceae Schimp. (Musci, Hypnales). - Taxon 54: 651-663.

GOLOBOFF, P.A. 1994. NONA: A Tree Searching Program. - Program and documentation, published by the author, Tucumán, Argentina.

HALL, T.A. 1999. BioEdit: a user-friendly biological sequence alignment editor and analysis program for Windows 95/98/NT. - Nucleic Acids Symposium Series 41: 95-98.

HEDENÄS, L. 1994. The Hedwigia ciliata complex in Sweden, with notes on the occurrence of the taxa in Fennoscandia. - Journal of Bryology 18: $139-157$

IGNATOV, M.S. \& O.M. AFONINA (eds.) 1992. Checklist of mosses of the former USSR. - Arctoa 1: 1-85.

IGNATOV M.S., B.C. TAN, Z. IWATSUKI \& E.A. IGNATOVA. 2000 Moss flora of the Upper Bureya River (Russian Far East). - Journal of Hattori Botanical Laboratory 88: 147-178.

IGNATOV, M.S., O.M. AFONINA, E.A. IGNATOVA et al.. 2006. Checklist of mosses of East Europe and North Asia. - Arctoa 15: 1-130.

IWATSUKI, Z. 2004. New catalog of the mosses of Japan. - Journal of the Hattori Botanical Laboratory 96: 1-182.

KEANE, T., C. CREEVEY, M. PENTONY, T. NAUGHTON \& J. MCLNERNEY. 2006. Assessment of methods for amino acid matrix selection and their use on empirical data shows that ad hoc assumptions for choice of matrix are not justified. - BMC Evol. Biol. 6: 29.

KOZUB, D., V. KHMELIK, Yu. SHAPOVAL, V. CHENTSOV, S. YATSENKO, B. LITOVCHENKO \& V. STARYKH. 2008. Helicon Focus Software. - http://www.heliconsoft.comNIXON, K.C. 1999a. Winclada (BETA) ver. 0.9.9. - Available at http://www.cladistics.com/ about_winc.html.

NIXON, K.C. 1999. Winclada (BETA) ver. 0.9.9. available at http:// www.cladistics.com/about_winc.html.

RAMBAUT, A. \& A.J. DRUMMOND. 2007. Computer program and documentation distributed by the author, website http://beast. bio.ed.ac.uk/Tracer.

RONQUIST, F., M. TESLENKO, P. VAN DER MARK, D.L. AYRES, A. DARLING, S. HÖHNA, B. LARGET, L. LIU, M.A. SUCHARD \& J.P. HUELSENBECK. 2012. MrBayes 3.2: Efficient Bayesian phylogenetic inference and model choice across a large model space. - Systematic Biology 61: 539-542.

STAMATAKIS, A. 2006. RAxML-VI-HPC: maximum likelihood-based phylogenetic analyses with thousands of taxa and mixed models. - Bioinformatics 22: 2688-2690.

Appendix 1

Species nam

H. ciliata s. str. 1406 Bulgaria

H. ciliata s. str. 1404 Belarus

specimen ID

ITS

Seregin \& Bocharnikov M-1026 (MW) KY358107

H. ciliata s. str.

Seregin \& SereginaM-1620 (MW) KY358099

KY358095

H. ciliata s. str. 1403 Russia, Murmansk Prov. Kozhin M-M-0847 (MW)

KY358096

H. ciliata s. str. 1386 Russia, Leningrad Prov. 14.05.1985, Ignatov (MHA)

KY358097

H. ciliata s. 1. 1401 Russia, Tver Province 18.07.1999, Notov (MW)

KY358108

H. ciliata s. $1 . \quad 1400$ Russia, Moscow

Kozhin \& Fedosov Msk-0007 (MW) KY358105

H. ciliata s. 1.516 Russia, Pskov Prov. 1

Afonina P1705 (LE)

KY358114

Zolotov P271 (MHA)

KY358113

$\operatorname{trnL}$

Nad5

H. ciliata s. $1 . \quad 1230$ Russia, Pskov Prov. 2

H. czernyadjevae 1357 Russia, Khabarovsk Territory 1

H. czernyadjevae 1321 Russia, Khabarovsk Territory 2

Khabarovsk Territory,

KY358120

KY358160

KY358153

KY356221

KY358149

KY358150

KY356214

KY356210

KY356211

KY358151

KY356212

KY358161

KY358158

KY356222

KY356219

KY358167 KY356228

Bureya, Ignatov 9-234 (MHA)

Khabarovsk, Bureya,

KY358166

KY356227

KY356233

Iwatsuki 60522 (MHA)

H. czernyadjevae 510

Russia, Khabarovsk

Iwatsuki 60261 (MHA)

KY358119

KY356232

Territory 3

H. czernyadjevae 452 Russia, Yakutia

Ignatov \& Ignatova 11-2234 (MHA) KY358116

KY358117 KY358170

H. czernyadjevae 511

Russia, Zabaikalsky

Czernyadjeva 37-11 (LE)

KY358118

KY358169

KY35623

Territory 1

H. czernyadjevae 512 Russia, Zabaikalsky Afonina 2911 (LE)

KY358115 KY358168

KY356231

Territory 2 


\begin{tabular}{|c|c|c|c|c|c|c|}
\hline H. emodica & 514 & $\begin{array}{l}\text { Russia, Zabaikalsky } \\
\text { Territory }\end{array}$ & Czernyadjeva 29-10 (LE) & KY358080 & KY358135 & KY356196 \\
\hline H. emodica & $\begin{array}{l}1318 \\
\text { Balka }\end{array}$ & $\begin{array}{l}\text { Russia, Kabardino- } \\
\text { ria } 1\end{array}$ & 01.08.2004, Ignatov et al. (MHA) & KY358125 & KY358177 & KY356238 \\
\hline $\begin{array}{l}\text { H. emodica } \\
\text { Balkaria } 2\end{array}$ & 1358 & Russia, Kabardino- & 29.07.2004, Ignatov et al. (MHA) & KY358121 & KY358173 & KY356234 \\
\hline H. emodica & $\begin{array}{l}517 \\
\text { Cherk }\end{array}$ & $\begin{array}{l}\text { Russia, Karachay- } \\
\text { essia }\end{array}$ & Shil'nikov 14952 (LE) & KY358122 & KY358174 & KY356235 \\
\hline H. emodica & 1399 & Russia, Dagestan & Fedosov 10-2-244 (MW) & KY358104 & KY358157 & KY356218 \\
\hline H. emodica & 451 & Russia, Perm Territory & Bezgodov 79 (MHA) & KY358111 & KY358164 & KY356225 \\
\hline H. emodica & 1402 & $\begin{array}{l}\text { Russia, Krasnoyarsk } \\
\text { Territory, Evenkia }\end{array}$ & Shcherbina 275 (MW) & KY358101 & - & KY356215 \\
\hline H. emodica & 1391 & Russia, Taimyr 1 & Fedosov 09-363 (MHA) & KY358088 & KY358142 & KY356203 \\
\hline H. emodica & 1397 & Russia, Taimyr 2 & Fedosov 05-92 (MW) & KY358103 & KY358156 & KY356217 \\
\hline H. emodica & 1226 & Russia, Yakutia & Ignatov \& Ignatova 15-1496 (MHA) & KY358123 & KY358175 & KY356236 \\
\hline H. emodica & 1393 & Russia, Amurskaya Prov. & Bezgodov 313 (MHA) & KY358089 & KY358143 & KY356204 \\
\hline H. emodica & 1323 & $\begin{array}{l}\text { Russia, Khabarovsk } \\
\text { Territory } 1\end{array}$ & Ignatov \& Ignatova 13-404 (MHA) & KY358126 & KY358178 & KY356239 \\
\hline H. emodica & 1356 & $\begin{array}{l}\text { Russia, Khabarovsk } \\
\text { Territory } 2\end{array}$ & Ignatov 97-2020 (MHA) & KY358128 & KY358180 & - \\
\hline H. emodica & 1359 & Russia, Primorsky Terr. & Ignatov 08-277 (MHA) & KY358127 & KY358179 & KY356240 \\
\hline H. emodica & 515 & Russia, Kamchatka & 21.08.2003, Czernyadjeva 105 (LE) & KY358124 & KY358176 & KY356237 \\
\hline H. mollis & 1388 & Russia, Murmansk & 04.08.1998, Ignatov (MHA) & KY358091 & KY358145 & KY356206 \\
\hline H. mollis & 1228 & Russia, Karelia & $\begin{array}{l}\text { Bakalin \& Bakalina, } \\
\text { Bryoph. Karelica Exs } 33 \text { (MHA) }\end{array}$ & KY358081 & KY358136 & KY356197 \\
\hline H. mollis & 1387 & Russia, Tula Province & 11.08.1983, Popova (MHA) & KY358090 & KY358144 & KY356205 \\
\hline H. mollis & 1389 & Russia, Lipetzk Province & 07.06.1986, Popova (MHA) & KY358100 & KY358154 & - \\
\hline H. mollis & 1407 & Russia, Kursk Province & Poluyanov 101G (MW) & KY358110 & KY358163 & KY356224 \\
\hline H. mollis & 1229 & $\begin{array}{l}\text { Russia, Karachay- } \\
\text { Cherkessia }\end{array}$ & $\begin{array}{l}\text { Ignatov \& Ignatova } \\
05-3103 \text { (MHA) }\end{array}$ & KY358082 & KY358137 & KY356198 \\
\hline H. mollis & 1408 & $\begin{array}{l}\text { Russia, Kabardino- } \\
\text { Balkaria }\end{array}$ & 14.08.2007, Konovalova (MHA) & KY358130 & KY358182 & KY356242 \\
\hline H. mollis & 1227 & Russia, Orenburg & 1.09.2004, Spirina \& Zolotov (MHA) & KY358079 & 58134 & KY356195 \\
\hline H. mollis & 1392 & Russia, Bashkortostan & Zolotov 13-18 (MHA) & KY358102 & KY358155 & KY356216 \\
\hline H. mollis & 1322 & Russia, Altai & Ignatov \& Ignatova 12-520 (MHA) & KY358083 & KY358138 & KY356199 \\
\hline H. nemoralis & 1385 & Russia, Kaluga Prov. & Teleganova 04-1 (MHA) & KY358098 & KY358152 & KY356213 \\
\hline H. nemoralis & 1231 & $\begin{array}{l}\text { Russia, Krasnodar } \\
\text { Territory, Sochi }\end{array}$ & Ignatov \& Ignatova 12-89 (MHA) & KY358084 & KY358139 & KY356200 \\
\hline H. nemoralis & 1394 & Georgia, Adjaria & Bakalin G-11-60-13 (MHA) & KY358093 & KY358147 & KY356208 \\
\hline H. nemoralis & 513 & Russia, Zabaikalsky Terr & r. Afonina 3411 (LE) & KY358086 & KY358140 & KY356201 \\
\hline H. nemoralis & 1320 & Russia, Primorsky Terr. & Ignatov 07-324 (MHA) & KY358087 & KY358141 & KY356202 \\
\hline H. nemoralis & 1405 & U.S.A., Missouri & Bakalin \& Brinda US-41-37-14 (MW) & KY358109 & KY358162 & KY356223 \\
\hline$H . \mathrm{sp}$. & 1395 & $\begin{array}{l}\text { Russia, Krasnodar } \\
\text { Territory, Novorossijsk }\end{array}$ & Ignatov \& Ignatova 05-223 (MHA) & KY358094 & KY358148 & KY356209 \\
\hline H. sp. & 1411 & Russia, Amurskaya Prov. & . Dudov Br_12_044 (MW) & KY358133 & KY358185 & KY356245 \\
\hline H. sp. & 1409 & Russia, Khabarovsk Terr & r. Ignatov \& Ignatova 13-1128 (MHA) & KY358131 & KY358183 & KY356243 \\
\hline H. sp. & 1319 & $\begin{array}{l}\text { Russia, Primorsky } \\
\text { Territory } 1\end{array}$ & Ignatov et al.06-2857 (MHA) & KY358129 & KY358181 & KY356241 \\
\hline H. sp. & 1410 & Russia, Primorsky Terr.2 & 2Ignatov et al. 13-1801 (MHA) & KY358132 & KY358184 & KY356244 \\
\hline H. cf. stellata & 1398 & Norway, Bergen 1 & Ignatov \& Ignatova 06-5134 (MW) & KY358106 & KY358159 & KY356220 \\
\hline H. cf. stellata & 450 & Norway, Bergen 2 & Ignatov \& Ignatova 06-5134 (MW) & KY358112 & KY358165 & KY356226 \\
\hline
\end{tabular}

GenBank accession numbers for nad5/ rps4/rbcL: Braunia alopecura (Brid.) Limpr. 1 LN714248/ LN714302/ LN714276; B. alopecura 2 LN714249/ LN714303/ LN714277; B. imberbis (Sm.) N. Dalton \& D. G. Long 1 LN714250/ LN714304/ LN714278; B. imberbis 2 LN714251/ LN714305/ LN714279; B. imberbis 3 LN714252/ LN714306/ LN714280; Hedwigia californica (Lesq.) Kindb.) LN714253/ LN714308/ LN714281; H. ciliata s. 1. (Hedw.) P. Beauv. Kenya LN714240/ LN714327 LN714272; H. ciliata s. str. Sweden LN714264/ LN714319/ LN714292; H. ciliata s. str. Germany 1 LN714255/ LN714310/ LN714283; H. ciliata s. str. Germany 2 LN714256/ LN714311/ LN714284; H. ciliata s. str. Germany 3 HF536705/ LN714311/ LN714284; H. ciliata s. 1. Sweden 1 LN714262/ LN714317/ LN714290; H. ciliata s. 1. Sweden 2 LN714263/ LN714318/ LN714291; H. emodica Hampe ex Müll. Hal.? (as H. ciliata) Spain LN714239/ LN714328/ LN714273; H. detonsa (M. Howe) W.R. Buck \& D.H. Norris LN714254/ LN714309 LN714282; H. emodica? (as H. ciliata) LN714261/ LN714316/ LN714289; H. stellata Hedenäs Germany 1 LN714267/ LN714322/ LN714295; H. stellata Germany 2 LN714268/ LN714323/ LN714296; H. stellata Sweden LN714269/ LN714324/ LN714297; H. striata (Wilson) Bosw. Spain LN714265/ LN714320/ LN714293; H. striata Portugal LN714266/ LN714321/ LN714294; Rhacocarpus purpurascens (Brid.) Paris LN714247/ AY908381/ AY908381. 